\title{
INDICADORES DE VIOLENCIA DE GÉNERO
}

EN LAS RELACIONES AMOROSAS.

\author{
ESTUDIO DE CASO EN ADOLESCENTES CHILENOS
}

\author{
INDICATORS OF GENDER VIOLENCE \\ IN ROMANTIC RELATIONSHIPS. CASE STUDY IN CHILEAN ADOLESCENTS
}

\author{
INDICADORES DE VIOLÊNCIA DE GÊNERO \\ NOS RELACIONAMENTOS AMOROSOS. ESTUDO DE CASO \\ EM ADOLESCENTES CHILENOS
}

\author{
Maria Cruz Sánchez Gómez y Antonio Víctor Martín García \\ UNIVERSIDAD DE SALAMANCA, ESPAÑA
}

\section{Beatriz Palacios Vicario}

Universidad de Pontificia de Salamanca, España

RESUMEN: La presencia de la violencia de género aumenta de forma alarmante en nuestra sociedad y se ha convertido en un problema social de primer orden. Los datos indican que el origen de bastantes de estos comportamientos hunde sus raíces en las primeras relaciones que se dan en la adolescencia, donde se ha comprobado la presencia y repetición de patrones y modelos machistas. Asumimos en este trabajo que estas conductas están relacionadas con comportamientos socialmente aceptados y que forman parte de los patrones normativos propios de los procesos de socialización. Para analizar esta tesis, un grupo interdisciplinar de investigadores pertenecientes a universidades españolas y chilenas realizó un estudio cualitativo sobre los comportamientos asociados a la violencia de género en grupos de adolescentes y jóvenes de diferentes contextos económicos, geográficos, sociales y étnicos, con el objetivo de aportar evidencias sobre el modo en que los adolescentes establecen sus relaciones de pareja y determinar si en estas relaciones existen indicios de violencia de género ejercida contra la mujer adolescente. Se propuso un diseño tomando como referencia los principios de la Grounded Theory, utilizando el método comparativo constante, es decir, la recolección de información, codificación y el análisis de la misma se realizan simultáneamente, y el muestreo teórico implica seleccionar nuevos casos en función de su potencial para ayudar a refinar o expandir los conceptos y teorías ya desarrollados. De este modo, la codificación de los discursos se realizó de forma abierta, axial y selectiva, agrupando, finalmente las categorías o ideas relevantes de los datos en metacategorías para construir el esquema teórico. En el estudio participaron 156 adolescentes (77 chicas y 79 chicos) residentes en la zona urbana de la región de Arica de Chile, siendo seleccionadas en función de las variables "curso académico" y "edad", configurándose 17 grupos de discusión hasta conseguir la saturación de la información. 
Los resultados ponen de manifiesto que en estas primeras relaciones de pareja de los adolescentes hay un número importante de referencias a lo negativo y a comportamientos de violencia de género, sobre todo a la violencia psicológica, en la que aparece una clara esquematización rígida de roles de género, culturalmente asimilados y donde los valores de fuerza, poder y dominio aparecen como valores propios de la identidad masculina. Estos "valores" fundamentan estructuras de desigualdad, y un medio para alcanzarlos y defenderlos es la agresión. Como contrapartida, la identidad femenina se elabora con los atributos de debilidad, control y necesidad de protección. Estos valores son transmitidos como pautas de comportamiento deseable y se insertan en la propia identidad de la mujer adolescente. Se discute finalmente la necesidad de mayor esfuerzo institucional en la mejora de los programas de igualdad y en el desarrollo de propuestas educativas que permitan priorizar y diseñar programas de intervención para promover relaciones más igualitarias entre adolescentes y jóvenes, como medio de educar para la prevención de conductas abusivas en las relaciones de noviazgo juvenil y la construcción de relaciones amorosas no agresivas.

PALABRAS CLAVE: Adolescentes; actitudes adolescentes; relaciones de pareja; violencia de género; sexismo

ABSTRACT: The presence of gender violence is increasing alarmingly in our society and has become one of our most serious social problems. The data indicate that the origin of much of this type of behaviour has its roots in early adolescent relationships, in which the presence and repetition of chauvinist patterns and models has been verified. In this paper we assume that this kind of conduct is related to socially accepted behaviours that form part of the normative patterns typical of socialization processes. To analyse this thesis, an interdisciplinary group of researchers from Spanish and Chilean universities carried out a qualitative study on behaviours associated with gender violence in groups of adolescents and young people from different economic, geographic, social and ethnic contexts in order to gather evidence about the ways adolescents establish romantic or intimate relationships and to determine whether there are any indications of male chauvinist violence against adolescent women. The research design proposed takes as a reference the principles of Grounded Theory and employs the constant comparative method, that is, the information is collected, coded and analysed simultaneously, with theoretical sampling that involves selecting new cases as a function of their potential to help refine or expand the concepts and theories already developed. Thus, the coding of the discourse was carried out using open coding, axial coding and selective coding, and finally grouping the relevant categories or ideas into meta-categories to build the theoretical schema. Participating in the study were 156 adolescents ( 77 girls and 79 boys) residing in the urban area of the Arica region in Chile, having been selected according to the variables "academic year" and "age". Seventeen discussion groups were formed until data saturation was attained. The findings show that in these first adolescent dating relationships there is an important number of negative references and references to violent chauvinist behaviour, in particular psychological violence, in which there is a clear, rigid, culturally assimilated structuring of gender roles in which the values of strength, power and dominance appear as belonging to a masculine identity. These "values" are at the basis of structures of inequality, and one means of attaining them and defending them is through aggression. In contrast, female identity is constructed with the attributes of weakness, control and need for protection. These values are transmitted as norms of desirable behaviour and are inserted into the very identity of adolescent women. Finally we discuss the need for greater institutional resolve in the improvement of equality programs and the development of educational proposals to enable intervention programs to be designed and prioritized. This should be done with a view to promoting more egalitarian dating relationships in adolescence and young adulthood, as a means to educate for prevention of abusive behaviour in adolescent dating and the construction of non-aggressive love relationships.

KEYWORDS: Adolescents; Attitudes Adolescent; Couple's Relationships; Gender violence; Sexism

[ 86 ] MARIA CRUZ SÁNCHEZ GÓMEZ, BEATRIZ PALACIOS VICARIO Y ANTONIO VÍCTOR MARTÍN GARCÍA SIPS - PEDAGOGIA SOCIAL. REVISTA INTERUNIVERSITARIA [1139-1723 (2015) 26, 85-109] TERCERA ÉPOCA 
RESUMO: A presença da violência de género aumenta de forma alarmante na nossa sociedade e tornouse um problema social relevante. Os dados indicam que a origem de muitos destes comportamentos está enraizada nos primeiros relacionamentos que ocorrem na adolescência, onde se verificou a presença e repetição de padrões e modelos machistas. Assumimos neste trabalho que estas condutas estão relacionadas com comportamentos socialmente aceites e que fazem parte dos padrões normativos próprios dos processos de socialização. Para analisar esta tese, um grupo interdisciplinar de investigadores de universidades espanholas e chilenas realizou um estudo qualitativo sobre os comportamentos associados com a violência de género em grupos de adolescentes e jovens de diferentes contextos económicas, geográficos, sociais e étnicos, com o objetivo de fornecer evidências sobre o modo como os adolescentes estabelecem as suas relações de namoro e determinar se nessas relações existem indícios de violência machista exercida contra a mulher adolescente. Propôs-se um desenho, tendo como referência os principios da Grounded Theory, utilizando o método comparativo constante, ou seja, a recolha de informação, codificação e análise da mesma realizam-se simultaneamente e a amostragem teórica implica seleccionar novos casos em função do seu potencial para ajudar a refinar ou expandir os conceitos e teorías já desenvolvidos. Deste modo, a codificação dos discursos realizou-se de forma aberta, axial e seletiva, agrupando, finalmente as categorías ou ideias relevantes dos dados em metacategorias para construir o esquema teórico. Participaram no estudo 156 adolescentes (77 raparigas e 79 rapazes) residentes na zona urbana da região de Arica de Chile, sendo selecionados em função das variáveis "curso académico" e idade, configurando-se 17 grupos de discussão até se conseguir a saturação de informação.

Os resultados mostram que nestes primeiros relacionamentos de namoro dos adolescentes há um número significativo de referências a aspetos negativos e a comportamentos de violência machista, especialmente a violência psicológica, na qual aparece uma clara esquematização rígida de papeis de género, culturalmente assimilados e onde os valores de força, poder e domínio aparecem como valores próprios da identidade masculina. Estes "valores" fundamentam estruturas de desigualdade, e um meio para alcançá-los e defendê-los é a agressão. Como contrapartida, a identidade feminina forma-se com os atributos de debilidade, controlo e necessidade de proteção. Estes valores são transmitidos como padrões de comportamento desejável e inserem-se na própria identidade da mulher adolescente. Finalmente, discute-se a necessidade de um maior esforço institucional na melhoria dos programas de igualdade e no desenvolvimento de propostas educativas que permitam priorizar e desenhar programas de intervenção para promover relações mais igualitárias entre adolescentes e jovens, como meio de educar para a prevenção de condutas abusivas nas relações de envolvimento juvenil e a construção de relações amorosas não agressivas.

PALAVRAS-CHAVE: Adolescentes; As relações do casal; violência de gênero; sexismo

\section{Introducción}

La presencia de la violencia de género en nuestra sociedad y su relevancia ha sido considerado por Naciones Unidas como el crimen privado más extendido del mundo (ONU, 2O13). El Fondo de Desarrollo de Naciones Unidas para la Mujer (UNIFEM) declaró ya en 1995 que la violencia de género va total y directamente en contra de todos los objetivos del desarrollo. Los datos de la última macro-encuesta realizada por la Unión Europea (European Union Agency for Fundamental Rights, 2014), realizada mediante entrevistas personales a 42000 mujeres en

\section{Introduction}

The presence and significance of gender-based violence in our society has led to the United Nations considering it to be the most widespread private crime in the world (UN, 2013). The United Nations Development Fund for Women (UNIFEM) declared as far back as 1995 that gender-based violence is entirely and directly contrary to any development goal. The data of the last macrosurvey carried out by the European Union (European Union Agency for Fundamental Rights, 2014), which was based on personal interviews with 42,000 women in the 28 
los 28 Estados miembros de la UE y con una media de 1500 entrevistas por país, muestran tasas de violencia realmente preocupantes, siendo los países nórdicos los que se sitúan a la cabeza con porcentajes como el 52\% en Dinamarca, seguida de Finlandia y Suecia con un $47 \%$ y $46 \%$ respectivamente. España se sitúa en el puesto 26 de 29 países encuestados, con una tasa relativamente menor del $22 \%$, quedando por debajo de la media europea que se sitúa en el 33\% de mujeres víctimas de violencia de género. A pesar de ello, en 2014 hubo en España 53 víctimas mortales por violencia de género, de las cuales sólo 17 había interpuesto la denuncia correspondiente y en lo que llevamos del año 2015, han fallecido hasta la fecha cuatro mujeres, de las cuales sólo una de ellas había denunciado a su agresor (Ministerio de Sanidad, Servicios Sociales e Igualdad, 2014, 2015). Casi 62.000 mujeres víctimas de violencia de género viven con algún tipo de medida de seguimiento y de vigilancia por parte de las Fuerzas y Cuerpos de Seguridad de Estado y 15.500 tienen protección policial en situación de riesgo extremo o alto de ser agredidas por sus parejas o exparejas (datos procedentes del informe elaborado por el Observatorio español contra la Violencia Doméstica y de Género, 2013).

Referido al caso concreto de los adolescentes y jóvenes (13 a 19 años) la violencia de género y los patrones sexistas evolucionan también de forma alarmante. En 2013 hubo 151 menores enjuiciados y se impusieron medidas a 130, observándose un marcado aumento de denuncias judiciales, así como mayor reconocimiento entre los adolescentes de comportamientos agresivos o machistas. Al respecto, el informe del Ministerio de Sanidad revela que un $23 \%$ de las chicas reconocen haber sufrido conductas violentas como insultos o haber sido ridiculizadas. Si nos situamos en el contexto latinoamericano, y particularmente en el caso de Chile, las cifras sobre violencia de género no son muy diferentes. Los datos muestran que en el año 2013 se registraron un $28 \%$ de casos de violencia más que en 2012 , y un incremento del $15,4 \%$ en atención especializada a mujeres maltratadas. El Observatorio de Equidad de Género en Salud chileno (OEGS), en su informe de 2013 sobre la Violencia de Género, señala que en el periodo que va desde el 2004 al 2011 se incrementaron un 9.2\%, las denuncias interpuestas por muje- member states of the EU and involved an average of 1,500 interviews per country, show truly worrying rates of violence. The Nordic countries displayed the highest rates: $52 \%$ of women were victims of gender-based violence in Denmark, followed by Finland and Sweden with $47 \%$ and $46 \%$ respectively. Spain is ranked 26 th out of the 28 countries surveyed, with a relatively lower rate of $22 \%$, a figure that places it below the European average, which stands at 33\%. In spite of Spain's lower ranking, in 2014 there were 53 fatalities that were a result of gender-based violence in the country, of which only 17 victims had previously lodged a complaint related to domestic violence. And so far in 2015 , four women have died, of which only one had made a complaint against her attacker (Ministerio de Sanidad, Servicios Sociales e Igualdad, 2014, 2015). Almost 62,000 women victims of gender-based violence in Spain live under some kind of monitoring and surveillance measure overseen by the state's security bodies, and 15,500 have police protection and are in a situation of extreme or high risk of being attacked by their partners or ex-partners (data from the report prepared by the Observatorio español contra la Violencia Doméstica y de Género [The State Observatory on Violence against Women], 2013).

With regard to adolescents and young people (13-19 years old) specifically, gender-based violence and sexist patterns are also evolving at an alarming rate. In 2013, 151 were prosecuted, and measures were imposed on 130; these figures represent a marked increase in criminal complaints, as well as a greater recognition among adolescents of aggressive or sexist behavior. In this regard, a Ministry of Health report reveals that $23 \%$ of girls acknowledge having suffered violent behaviors such as insults or ridicule. In Latin America, and in Chile in particular, the figures on gender-based violence are not very different. The data show that in 2013 there were $28 \%$ more cases of violence than there were 2012 , and an increase of $15.4 \%$ in specialized care provided to abused women. Chile's Observatory on Gender Equity in in Health (Observatorio de Equidad de Género en Salud; OEGS) revealed in its 2013 report on gender-based violence that in the period between 2004 and 2011 complaints filed by women increased by $9.2 \%$ and that there has been a rise in

[ 88 ] MARIA CRUZ SÁNCHEZ GÓMEZ, BEATRIZ PALACIOS VICARIO Y ANTONIO VÍCTOR MARTÍN GARCÍA SIPS - PEDAGOGIA SOCIAL. REVISTA INTERUNIVERSITARIA [1139-1723 (2015) 26, 85-109] TERCERA ÉPOCA 
res, existiendo un repunte de las denuncias por violencia sexual en adolescentes entre 15 y 19 años.

\section{Fundamentación}

\subsection{Breve conceptualización de la violencia de género. Factores multicausales de riesgo}

La "Declaración sobre la eliminación de la violencia contra la mujer" (Resolución de la Asamblea General 48/104, ONU, 1994) constituye el primer instrumento internacional de derechos humanos que aborda de forma explícita este problema. Según esta Declaración la violencia de género es:

\footnotetext{
"todo acto de violencia basado en la pertenencia al sexo femenino que tenga o pueda tener como resultado un daño físico, sexual o psicológico para la mujer, así como las amenazas de tales actos, la coacción o la privación arbitraria de la libertad, tanto si se producen en la vida pública como en la vida privada"
}

Heyzer (2000), señala que esta Declaración marcó un hito histórico por tres razones básicas: En primer lugar porque colocó a la violencia de género en el marco de los Derechos Humanos, y por lo tanto se considera un problema social. En segundo lugar, porque amplió el concepto de violencia de género, incluyendo tanto la violencia física, psicológica o sexual, como las amenazas de sufrirla en el contexto familiar, de la comunidad o del estado. En tercer lugar, porque resaltó que se trata de una forma de violencia basada en el género, de modo que el factor de riesgo para padecerla es precisamente ser mujer. Es decir, se trata de aquellas formas de violencia que son ejercidas por los varones contra las mujeres por el hecho de serlo y por la posición social que ocupan unos y otras en razón de los condicionantes que introduce el género (roles y posición social subordinada en el caso de las mujeres, roles y posición social dominante en el caso de los varones). Para Bosch, Ferrer, y Alzamora (2006) habría que añadir una cuarta razón y es el hecho de que esta definición se ha llegado a convertir en el marco común que manejan en la actualidad la gran mayoría de los organismos nacionales e internacionales (como la propia ONU, la OMS, la Comisión Europea,...) que se ocupan de su análisis, ya que, ofrece un marco complaints relating to sexual violence made by teenagers aged between 15 and 19 years.

\section{Basis}

\subsection{Brief conceptualization of gender-based violence: Multicausal risk factors}

The Declaration on the Elimination of Violence Against Women (General Assembly resolution 48/104, UN, 1994) is the first international humanrights instrument that explicitly addresses this problem. According to the declaration, gender-based violence is

"any act of gender-based violence that results in, or is likely to result in, physical, sexual or psychological harm or suffering to women, including threats of such acts, coercion or arbitrary deprivation of liberty, whether occurring in public or in private life."

Heyzer (2000) argues that this statement was a historical milestone, for three basic reasons. First, because it placed gender-based violence in the context of human rights, and therefore it is considered to be a social problem. Second, because it expanded the concept of gender-based violence so that it includes physical, psychological, and sexual violence as well as threats of it in the context of the family, the community, or the state. Third, because the gender dimension of the violence is highlighted-the risk factor for suffering from it is precisely the fact of being a woman. That is, the term covers forms of violence that are carried out by men against women because of who they are and because of the social position that each occupies due to the conditioning introduced by gender (subordinate roles and social position in the case of women, dominant roles and social position in the case of men). For Bosch, Ferrer, and Alzamora (2006), a fourth reason should be added: the fact that this definition has become the common framework used by the vast majority of national and international agencies (such as the UN itself, the WHO, and the European Commission) in conducting their analysis, since it offers a widely accepted conceptual framework on what domestic violence is and what it means. 
conceptual ampliamente aceptado sobre lo que la violencia de género es y significa.

En el estudio de Moreno, Sastre y Hernández (2003) sobre la elaboración de los modelos de género en adolescentes encontraron que ya en la adolescencia (entre 12 a 16 años) los procesos de socialización pueden dar lugar a representaciones mentales que contienen el germen de la tolerancia o intolerancia y de la aceptación o negación de la violencia de género. Estas autoras consideran que el maltrato está basado en la creencia en la desigualdad de derechos y deberes entre los sexos y en la pervivencia de una concepción de roles de género que supeditan la mujer al hombre en las relaciones de pareja. Los resultados que obtuvieron indican que las chicas más jóvenes son las que más cuenta se dan de situaciones de maltrato y se oponen a él, pero las adolescentes de más edad son más tolerantes al maltrato y las situaciones de violencia de género, lo que parece que pudiera ser debido al deseo de ser aceptadas por los chicos, adoptando el modelo complementario de ellos. Díaz-Aguado (2000) también encontró que las creencias sexistas y la justificación de la violencia se da en mayor grado en los varones que en las mujeres adolescentes. Y los estudios de Bosch y Ferrer (2002) establecen la evidencia de la relación directa que existe entre las creencias misóginas de los varones y la violencia de género. Sin embargo, podemos decir que entre el $70 \%$ y $98 \%$ de las chicas y entre el $43 \%$ y $86 \%$ de los chicos, es decir, una gran mayoría de los adolescentes y jóvenes, rechazan las creencias que justifican la violencia de género (Díaz-Aguado, 2003, 2006).

En la literatura especializada sobre el tema se han identificado algunos factores de riesgo que influyen en una mayor o menor tolerancia a la violencia de género. Siguiendo a Santos (2009) presentamos una síntesis de estos factores multicausales de riesgo:

- El género es la variable que mejor explica la mayor tolerancia a la violencia de género y en concreto las actitudes sexistas de cualquier tipo sea hostil o benévolo. También explica el desarrollo de los micromachismos, es decir, las creencias y actitudes hacia la violencia de género.

- El tipo de educación recibida y los modelos observados, sobre todo la educación igualitaria
Moreno, Sastre and Hernández (2003) found in a study on the development of gender models in adolescents that as early as adolescence (ages 12 to 16) socialization processes can give rise to mental representations that contain the seed of tolerance or intolerance and of the acceptance or rejection of gender-based violence. These authors consider that abuse is based on a belief in an inequality of rights and duties between the sexes and the survival of a conception of gender roles that subordinates women to men in relationships. The results they obtained indicate that younger girls are the group that are most aware of situations of abuse and opposed it, but older adolescents are more tolerant of abuse and situations of gender violence, possibly due to a desire to be accepted by boys and an adoption of a complementary model to their own. Díaz-Aguado (2000) also found that sexist beliefs and a justification of violence are more commonly exhibited by adolescent men than they are by adolescent women. And studies by Bosch and Ferrer (2002) establish evidence of the direct relationship between men's holding of misogynist beliefs and gender-based violence. However, we can say that between $70 \%$ and $98 \%$ of girls and between $43 \%$ and $86 \%$ of boys-that is, a large majority of adolescents and young people-reject beliefs that justify gender-based violence (Díaz-Aguado, 2003, 2006).

In specialist literature on the subject, certain risk factors that stimulate a greater or lower tolerance to violence against women have been identified. In accordance with Santos (2009), we present a summary of these multicausal risk factors:

- Gender is the variable that best explains greater tolerance to violence against women, and in particular sexist attitudes of any kind-whether benevolent or hostile ones-and the development of micromachismos of beliefs and attitudes towards gender-based violence.

- The type of education received and the models observed, especially equal education for brothers and sisters and the employment situation of parents, also contribute to predicting sexism and tolerance towards gender-based violence.

- The specific education received relating to gender-based violence, both as a specific subject and in the form of courses, seminars, or other activities. This factor indicates that it is highly ad-

[ 90 ] MARIA CRUZ SÁNCHEZ GÓMEZ, BEATRIZ PALACIOS VICARIO Y ANTONIO VÍCTOR MARTÍN GARCÍA SIPS - PEDAGOGIA SOCIAL. REVISTA INTERUNIVERSITARIA [1139-1723 (2015) 26, 85-109] TERCERA ÉPOCA 
ente hermanos y hermanas y la situación laboral de los padres, contribuyen también a predecir el sexismo y la tolerancia hacia la violencia de género.

- La formación específica recibida sobre violencia de género, tanto en asignaturas específicas como en forma de cursos, seminarios u otras actividades Este resultado indica que es muy recomendable incluir estos contenidos en el curriculum de las enseñanzas desde la Educación infantil hasta la Universidad, tal y como se propuso en la Ley Orgánica de Medidas de Protección Integral contra la Violencia de Género (BOE, $1 / 2004$ de 28 de diciembre).

- Las creencias sobre el amor romántico llevadas al límite.

- Las creencias o mitos sobre la violencia de género. Estos tópicos persisten en la actualidad, con tendencia a culpabilizar a la mujer y disculpar al varón.

\subsection{Contextualización del estudio}

El objetivo del estudio lo planteamos en términos de realizar un diagnóstico, a través de las relaciones de pareja, de los índices y formas de violencia de género en adolescentes de la zona urbana en la región de Arica (Chile), con la finalidad última de determinar las necesidades específicas que presenta esta población en materia de prevención y erradicación de la violencia de género. Las estadísticas indican que el $35,7 \%$ de las mujeres en Chile sufrió algún tipo de violencia durante el año 2011, concretamente estas cifras fueron: un $37,2 \%$ sufrió violencia psicológica, un $25 \%$ violencia física considerada leve o menos leve, un $15 \%$ violencia física grave, y el $15.6 \%$ había sufrido violencia sexual. Muchas de estas agresiones acabaron en feminicidios que son la máxima expresión de violencia hacia la mujer. Desde 2008 se registran oficialmente los feminicidios en Chile. A partir de esa fecha se han producido un total de 289 y 40 durante el año 2014 (SERNAN, 2015). Hay que destacar que la mayoría de los estos asesinatos fueron cometidos por quienes se encontraban en relación de pareja (cónyuges, convivientes, o parejas) y el porcentaje asciende a casi un 30\% cuando finaliza la relación, cifra que aumenta gradualmente (SERNAM, 2011). visable to include such content in the teaching curriculum from early childhood to university education, something proposed in the Organic Law on measures for Comprehensive Protection against Gender-Based Violence (Ley Orgánica de Medidas de Protección Integral contra la Violencia de Género; BOE, 1/2004 of December 28).

- Beliefs about romantic love taken to extremes. - Beliefs or myths about gender-based violence. These stereotypes persist today, with a tendency to blame the woman and excuse the male.

\subsection{Contextualization of the study}

We would put the objective of our study in terms of a diagnosis, carried out through couple relations, of the signs and forms of gender-based violence in adolescents in the urban area of the Arica region of Chile, with the ultimate aim of determining the specific needs exhibited by this population in terms of the prevention and eradication of gender-based violence. Statistics indicate that $35.7 \%$ of women in Chile suffered some form of violence during 2011. The specific figures were as follows: $37.2 \%$ suffered psychological violence, $25 \%$ a form of physical violence considered to be minor or less minor, 15\% severe physical violence, and $15.6 \%$ sexual violence. Many of these attacks ended in femicide, the most extreme expression of violence against women. Femicides have been officially recorded in Chile since 2008. Since that year, there has been a total of 289, and there were 40 during 2014 (SERNAN, 2015). It should be noted that the majority of these killings were committed by those who were in couple relationships (spouses, cohabitants, or partners); the figure reaches nearly $30 \%$ when a relationship comes to an end, a figure that is gradually increasing (SERNAM, 2011). 
Según datos facilitados por el Servicio Nacional de la Mujer (SERNAM, 2011), organismo encargado en Chile de recoger y analizar datos sobre la violencia de género, las mujeres entre 18 y 64 años fueron las que más sufrieron este tipo de violencia de género, existiendo un total de 3.518 denuncias, frente a las 267 interpuestas por los hombres del mismo grupo etario.

Gráfico 1. Prevalencia del tipo de violencia machista en Chile. adaptado de SERNAM (2011)

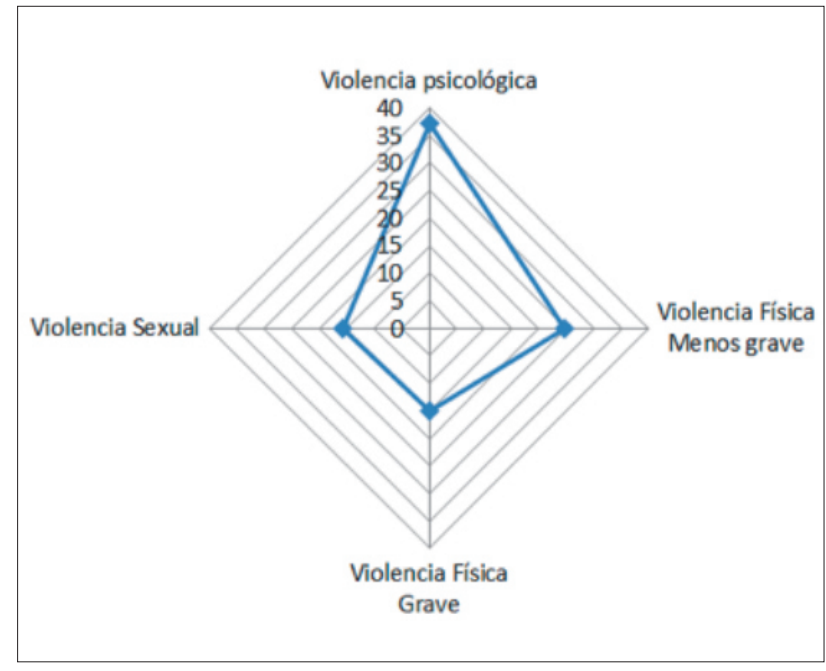

Por otro lado, la Encuesta de Prevalencia de la Violencia Intrafamiliar realizada el año 2011, muestra que la violencia empieza tempranamente en la relación de pareja. Por ejemplo, en la Región Metropolitana, de las mujeres que no conviven y que tienen una relación afectiva, un $11.6 \%$ ha sido víctima de violencia psicológica y un $12.2 \%$ física y/o sexual. Estas cifras aumentan significativamente en la relación de convivencia o matrimonio, en las que el $43.2 \%$ las mujeres afirman haber sufrido violencia psicológica, un $32.1 \%$ física y sexual un $14.9 \%$ (SERNAM, 2011).

Además, según esta misma fuente, si se tiene en cuenta la información que afecta a la juventud sobre los cambios en la construcción de los roles de género se percibe que un $6,4 \%$ de jóvenes sigue considerando que en las relaciones de pareja, el hombre posee el derecho de ejercer control sobre su mujer. En la misma encuesta se refleja que casi el $20 \%$ de las mujeres entre 15 y 29 años han experimentado violencia psicológica en sus relaciones de pareja; la mitad, casi un $10 \%$, señalan que han sufrido violencia física y, el 1\% manifiesta haber sufrido violencia sexual en este tramo de edad.
According to data provided by the National Service for Women (Servicio Nacional de la Mujer; SERNAM, 2011), a Chilean agency that is responsible for collecting and analyzing data on gender-based violence, women aged between 18 and 64 years were the most liable to suffer this type of gender-based violence. A total of 3,518 complaints were made by this group, compared with 267 filed by men from the same age group.

Chart 1. Prevalence of types of violence against women in Chile. Adapted from SERNAM (2011)

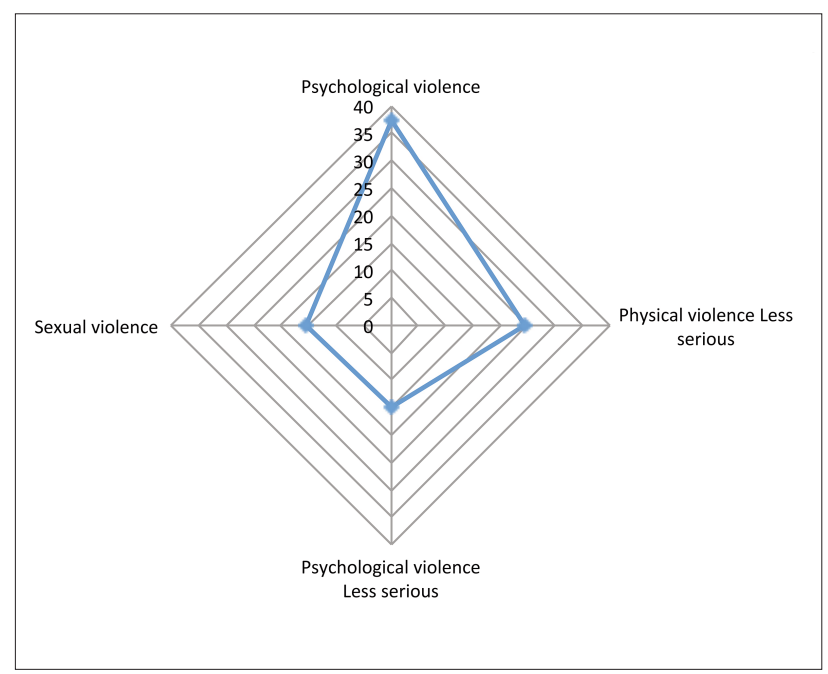

Moreover, the Survey on the Prevalence of Domestic Violence (Encuesta de Prevalencia de la Violencia Intrafamiliar) that was carried out in 2011 shows that violence begins at an early point in couple relationships. For example, in the Metropolitan Region, $11.6 \%$ of women who are in a relationship but do not live with their partner have been victims of psychological violence, and $12.2 \%$ have been victims of physi$\mathrm{cal}$ and/or sexual violence. These figures increase significantly in relationships in which the couple live together or are married. In total, $43.2 \%$ of women in these forms of relationships claim to have suffered psychological violence, 32.1\% physical and sexual violence, and $14.9 \%$ sexual violence (SERNAM, 2011).

In addition, according to this same source, if the information that affects young people with regard to changes in the construction of gender roles is taken into account, it emerges that $6.4 \%$ of young people continue to believe that the man has the right to exercise control over his wife in relationships. The same survey shows that nearly $20 \%$ of women aged between 15 and 29 years have experienced psychological violence in their couple relationships; half

[ 92 ] MARIA CRUZ SÁNCHEZ GÓMEZ, BEATRIZ PALACIOS VICARIO Y ANTONIO VÍCTOR MARTÍN GARCÍA SIPS - PEDAGOGIA SOCIAL. REVISTA INTERUNIVERSITARIA [1139-1723 (2015) 26, 85-109] TERCERA ÉPOCA 
Gráfico 2. Comparativa entre hombres y mujeres según los tipos de violencia (adaptado de SERNAM, 2011)

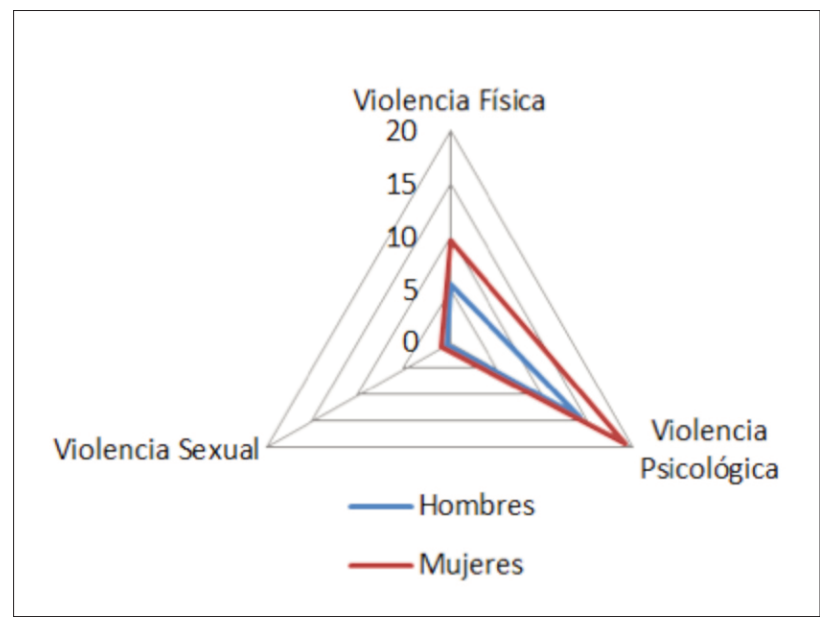

En relación con la población adolescente y de jóvenes de entre 15 y 29 años sobre las características de las primeras relaciones de pareja, se pone de manifiesto que un $12.2 \%$ dicen causar violencia psicológica a su pareja, no encontrándose diferencias significativas entre hombres y mujeres en violencia (datos de la Tercera Encuesta Nacional de Juventud, realizada el año 2000 (SERNAM, 2009).

\section{Metodología}

\subsection{Diseño}

A partir del objetivo general planteado surgen las siguientes preguntas de investigación: ¿pueden percibirse en las primeras relaciones amorosas de los adolescentes indicios de violencia de género?; ¿Puede sustentarse la violencia de género en una esquematización rígida de los roles de género, culturalmente asimilados?; ¿̇se pueden realizar propuestas educativas que permitan priorizar y diseñar programas de intervención para promover relaciones más igualitarias entre adolescentes y jóvenes, como medio de educar para la prevención de relaciones abusivas en las relaciones íntimas y desigualdades de género?.

Para dar respuesta a estas cuestiones y conseguir el objetivo propuesto se ha seguido un diseño de carácter cualitativo tomando como referencia los principios de la Grounded Theory (Strauss y Corbin, 1994), el método comparativo constante (la recolección de la información, la codificación y el análisis se realizan
Chart 2. Comparison between men and women according to types of violence (adapted from SERNAM, 2011)

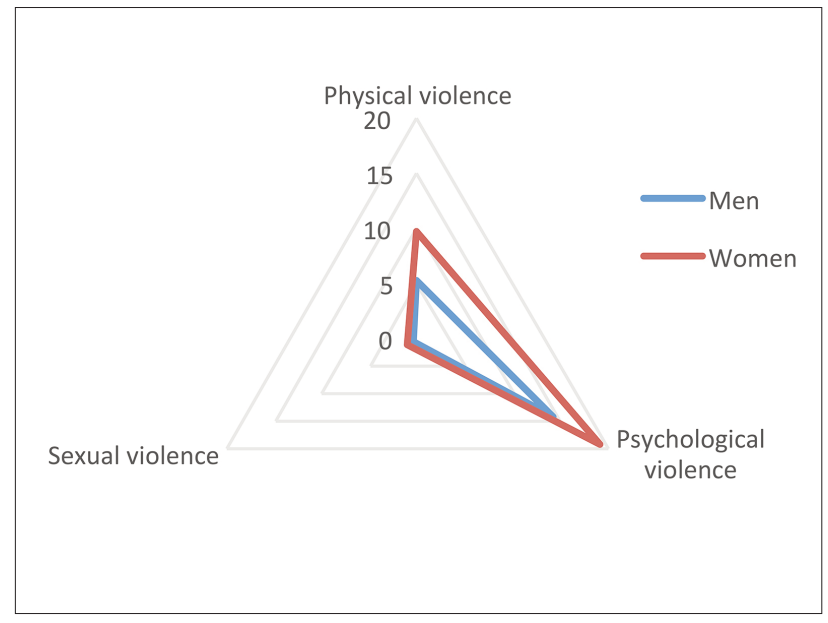

of them-so almost $10 \%$ in total-say they have suffered physical violence, and a total of $1 \%$ in this age bracket say they have suffered sexual violence.

With regard to the first couple relations of adolescents and young people aged between 15 and 29, $12.2 \%$ say they have inflicted psychological violence on a partner, and there were no significant differences between men and women in carrying out violence (data from the Third National Youth Survey [Tercera Encuesta Nacional de Juventud], conducted in 2000; SERNAM, 2009).

\section{Methodology}

\subsection{Design}

The following research questions arise from the proposed general objective: Can signs of gender-based violence be detected in the first romantic relations between adolescents? Is gender-based violence sustained in a rigid schematization of gender roles that are culturally assimilated? Is it possible to produce educational initiatives that allow the prioritizing and design of intervention programs to promote more equal relations among adolescents and young people, as a way of preventing abusive intimate relationships and gender inequalities through education?

To respond to these questions and achieve the proposed objective, a qualitative design has been followed. It takes as a reference the principles of Grounded Theory (Strauss and Corbin, 1994), the constant comparative method (data collection, coding, and analysis are 
simultáneamente) y el muestreo teórico (se seleccionan nuevos casos en función de su potencial para ayudar a refinar o expandir los conceptos y teorías ya desarrollados). Este modelo permite ejecutar tres operaciones importantes: las codificaciones abierta, axial y selectiva. Con dichas operaciones, se consigue identificar las categorías o ideas relevantes de los datos a analizar, describirlas, asignarles códigos y buscar, con criterios temáticos, relaciones entre ellas. Finalmente, se agruparán en metacategorías para construir el esquema teórico.

\subsection{Participantes, recogida de información y trabajo de campo}

La región de Arica (Chile), limita al norte con la República del Perú, al sur con la I Región de Tarapacá, al este con la República de Bolivia y al oeste con el océano Pacífico. Según el censo de 2002 (INE, 2002) la distribución de la población según pertenencia étnica es muy heterogénea. Se aprecia una elevada proporción del pueblo mapuche correspondiendo al $87,3 \%$ del total de la población indígena. Le siguen aymara (7\%) y atacameño (3\%). El resto de las etnias (colla, rapanui, quechua, yámana y alacalufe), suman en conjunto un $2,7 \%$. Estas cifras muestran que en esta región se encuentra una gran riqueza y diversidad cultural. Partiendo de estos datos generales y asumiendo que la muestra para un estudio cualitativo ha de ser acumulativa y secuencial hasta llegar a la saturación, garantizando la representatividad del discurso-significado, estimamos como posibles candidatos aquellos participantes que reunieran las características del perfil requerido. No se buscaron muestras representativas en sentido estadístico, con capacidad de inferencia a la población general, sino narraciones de adolescentes con capacidad de representar el espacio discursivo de su grupo de referencia; esto permitió conocer, analizar e interpretar las diferentes perspectivas sobre sus relaciones amorosas y la relación con conductas violentas por razones de género.

Teniendo en cuenta las consideraciones anteriores, los participantes fueron 156 adolescentes ( 77 chicas y 79 chicos) residentes en la zona urbana de la región de Arica de Chile, siendo seleccionadas en función de las variables "curso académico" y "edad": nivel 20 (14-15 años), nivel 30 (15-16 años) y nivel $4^{\circ}$ conducted simultaneously), and theoretical sampling (new cases are selected on the basis of their potential to help refine or expand already developed concepts and theories). This model allows three major operations to be executed: open, axial and, selective codings. With these operations, it is possible to identify the categories or ideas that are relevant to the data in order to analyze and describe them, assign them codes, and search, with thematic criteria, for relations between them. They would then finally be grouped into metacategories to construct a theoretical framework.

\subsection{Participants, collection of information, and field work}

The Arica region of Chile borders the Republic of Peru to the North, the I Tarapacá Region to the South, the Republic of Bolivia to the East, and the Pacific Ocean to the West. According to the 2002 census (INE, 2002) the distribution of the population according to ethnicity is very heterogeneous. There is a high proportion of Mapuche people; this group accounts for $87.3 \%$ of the total indigenous population. It is followed by the Aymara (7\%) and the Atacameño (3\%). The rest of the ethnic groups (the Colla, the Rapa Nui, the Quechua, the Yámana, and the Alacalufe) collectively make up the remaining $2.7 \%$. These data show that this region has a great cultural diversity and richness. On the basis of these general data, and assuming that the sample for a qualitative study should be cumulative and sequential until saturation is reached, ensuring the representativeness of the discourse/signifieds, we deemed as possible candidates the participants who met the characteristics of the required profile. We did not seek representative samples in a statistical sense, with the capacity for providing inferences on the general population. Instead, we sought accounts from adolescents who had the capacity to represent the discursive space of their reference group. Doing so allowed us to discover, analyze, and interpret the different perspectives on their romantic relationships and their relationships with violent behavior motivated by gender.

Taking into account the above considerations, the participants were 156 teenagers ( 77 girls and 79 boys) who were residents of the urban area of the Arica region of Chile. They were selected on the basis of the variables "school grade" and "age": the equivalents of US grade

[ 94 ] MARIA CRUZ SÁNCHEZ GÓMEZ, BEATRIZ PALACIOS VICARIO Y ANTONIO VÍCTOR MARTíN GARCÍA SIPS - PEDAGOGIA SOCIAL. REVISTA INTERUNIVERSITARIA [1139-1723 (2015) 26, 85-109] TERCERA ÉPOCA 
(16-17 años). La selección se realizó en centros públicos y subvencionados de Educación Media (Educación Secundaria Obligatoria y Bachillerato) y fue realizada por el orientador/a del centro (informante clave) y el personal investigador.

Imagen 1. Descripción de la muestra según las variables de selección

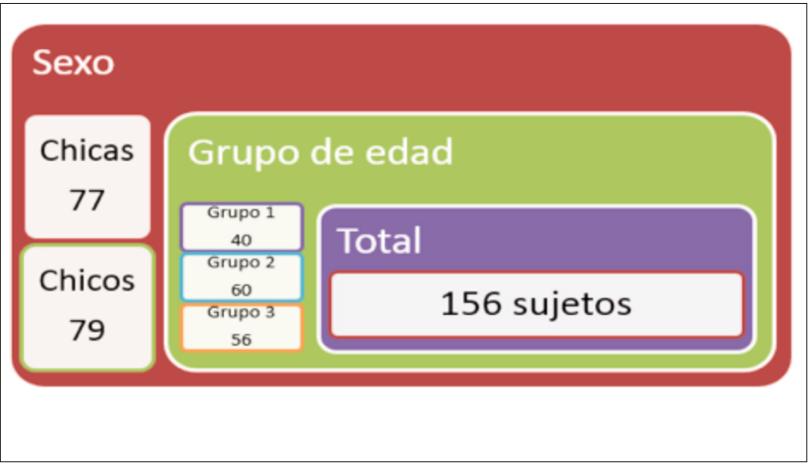

Para la recogida de datos se utilizó la técnica de grupos de discusión. El equipo consideró relevante utilizar esta técnica no solo para obtener la opinión de cada adolescente en particular, sino también su opinión en interacción con otros, con el fin de ampliar las posiciones discursivas del tema estudiado, así como observar en qué opiniones coincidían y/o discrepaban, las ideas nuevas que emergen en grupo.

Se realizaron 17 grupos de discusión hasta conseguir la saturación de la información, cada uno de ellos estuvo formado por 8-9 sujetos, la duración de la entrevista grupal fue de una hora, y quedaron grabadas en audio, previo consentimiento de los participantes. El discurso con el que se inició cada grupo de discusión fue "Vamos a tener un debate libre, cada persona puede decir lo que piensa, cada uno puede aportar sus ideas" y tenía que recoger información relativa al siguiente guión:

- Variables de identificación, niveles educativos, género y edad de los adolescentes.

- Características positivas y negativas de sus relaciones de pareja.

- Formas de violencia de género: subdividida en violencia de género psicológica y violencia de género física a través de los comentarios sobre sus relaciones amorosas.
9 (14-15 years), grade 10 (15-16 years), and grade 11 (16-17 years). The selection was carried out in public and subsidized secondary-education centers (at the equivalent level of US high school) and was performed by the center counselor (key informant) and research staff.

Image 1. Description of the sample according to selection variables

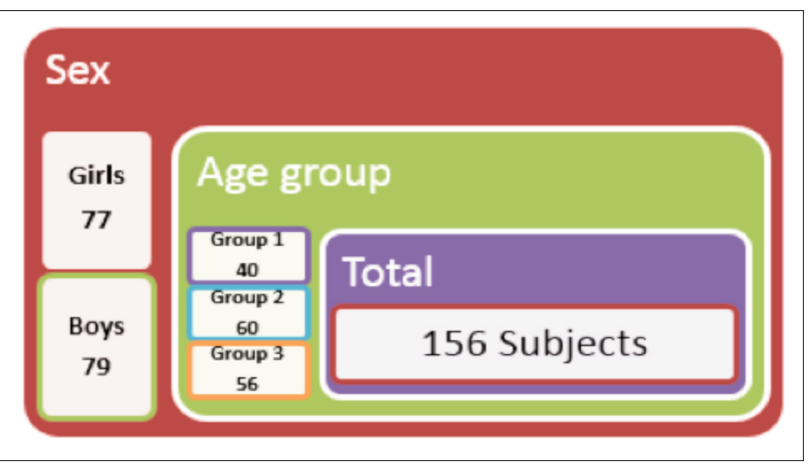

The discussion-groups technique was used for data collection. The team considered it appropriate to use this technique to obtain both the opinion of every individual teenager and his or her opinion during interaction with others, in order to expand the discursive positions of the subject studied, as well as to observe what opinions the new ideas that emerged in the group agreed or disagreed with.

A total of seventeen discussion groups were held until the point of information saturation was reached. Each group contained 8 or 9 subjects. The duration of the group interview was an hour, and an audio recording was made with the consent of the participants. Each discussion group began with the comment, "We are going to have a free debate. Each person can say what he or she thinks, and everyone can contribute his or her ideas." Information related to the following rubric was collected:

- Variables of identification, education levels, gender, and age of adolescents.

- Positive and negative features of their relationships.

- Forms of gender-based violence: subdivided into psychological violence and physical violence based on comments about their relationships. 


\subsection{Análisis}

Se realizó un análisis de contenido sobre las transcripciones de los grupos de discusión. De este análisis se obtuvieron resultados que hacen referencia al porcentaje e interpretación de discurso analizado y que corresponden a cada una de las categorías propuestas. En la primera fase del análisis cualitativo (categorización) se identificaron las ideas/categorías más importantes manifestadas por los adolescentes en los grupos.

A continuación, fusionando las ideas relevantes del contenido de los discursos de los adolescentes y los estudios teóricos sobre violencia de género en las relaciones de noviazgo juvenil heterosexual, sintetizadas en la escala VEC para la detección de la violencia psicológica en parejas heterosexuales (Delgado y Mergenthale, 2011; Cantera, Estébanez y Vázquez, 2009), se establecieron finalmente siete categorías principales de análisis y cincuenta y siete subcategorías. Como resultado, se elaboró el mapa conceptual del que presentamos las siete categorías principales.

Imagen 2. Sistema de categorías

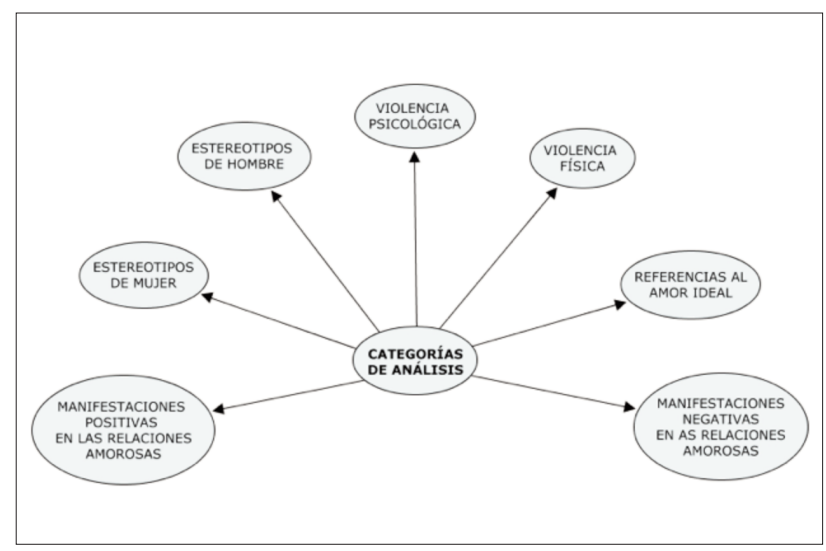

En la segunda fase del análisis se realizó la codificación axial y selectiva. Posteriormente y para la organización, clasificación y disposición de los datos textuales codificados en tablas y gráficas, se utilizó el programa análisis cualitativo NVIVOı. Durante esta fase se ha garantizado en todo momento los criterios de calidad en investigación cualitativa (Lincoln y Guba, 1985; Guba y Lincoln, 1989; Sánchez, Delgado y Santos, 2012, Palacios, Sánchez y Gutiérrez, 2013) que quedan sintetizados como sigue: la codificación se realizó por varios miembros del

\subsection{Analysis}

We conducted a content analysis of the transcripts of the discussion groups. From this analysis we obtained results that refer to the percentage and interpretation of analyzed speech and that correspond to each of the suggested categories. The most important ideas/categories expressed by the adolescents in the groups were identified in the first phase of the qualitative analysis (categorization).

Then, merging the relevant ideas from the content of the adolescents' discourse with theoretical studies on gender-based violence in heterosexual youth dating relationships, synthesized in the VEC scale for the detection of psychological violence in heterosexual couples (Delgado and Mergenthale, 2011; Cantera, Estébanez, and Vázquez, 2009), seven main categories of analysis and fifty-seven subcategories were finally established. As a result, we developed a conceptual map, from which we present the seven main categories.

Image 2. System of categories

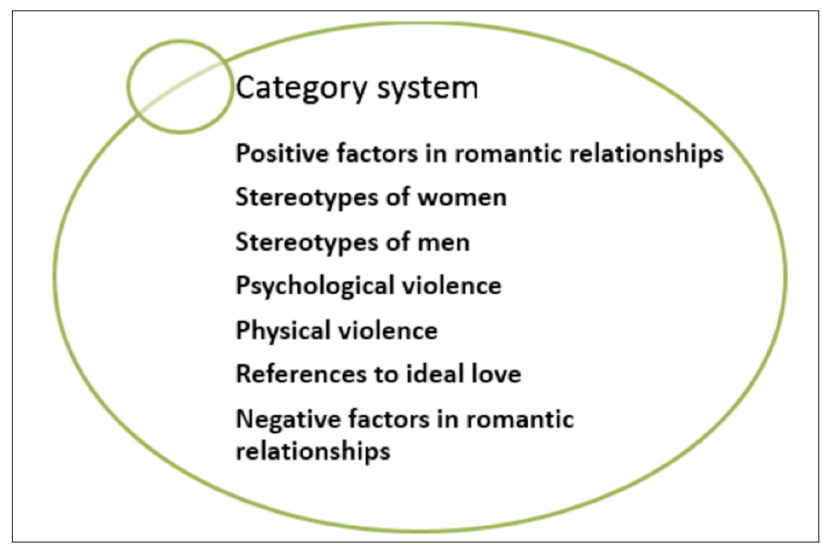

Axial and selective coding were performed in the second phase of the analysis. Later, and for the organization, classification, and arrangement of the textual data encoded in tables and graphs, we used the NVIVO1o qualitative-analysis program. During this phase, the criteria for qualitative-research quality were guaranteed (Lincoln and Guba, 1985; Guba and Lincoln, 1989; Sánchez, Delgado, and Santos, 2012; Palacios, Sánchez and Gutiérrez, 2013). These can be summarized as follows. Coding was conducted by several members of the research team 
equipo de investigación para así poder garantizar la credibilidad (validez interna) del proceso. Para probar la dependencia (fiabilidad) del sistema de categorías se elaboró un manual descriptivo de las mismas para realizar la codificación. Por último, la objetividad (Confirmabilidad) se ve reflejada en los resultados mediante la aportación de fragmentos literales del discurso de los adolescentes.

Adaptado de Delgado, Sánchez y Santos (2012) y tomando como referencia el manual de codificación realizado por expertos en violencia de género y presentado en el Informe del proyecto AECID "Diagnóstico de la incidencia y formas de violencia doméstica por razones de género en mujeres aymaras urbanas de la región de Arica y Parinacota, Chile" (2012) se elaboró una versión reducida del mismo que ayudó en la codificación de la información (identificar las categorías en los textos).

Imagen 3. Manual de codificación. Adaptado de Delgado, Sánchez y Santos (2013) e Informe de Memoria del proyecto "Diagnóstico de la incidencia y formas de violencia doméstica por razones de género en mujeres aymaras urbanas de la región de Arica y Parinacota. Chile (2012)

Violencia psicológica
- Control: saber todo lo que hace, con quién, controlar su forma de vestir y
arreglarse, lo que piensa... (ser aprensivo/a, ser posesivo)
- Acoso: vigilarla, seguirla, esperarla a la salida de los lugares a los que va sin que
ella lo desee, acosarla por telefono...Referencias a ser aprensivo/a (concepto
utilizado en Chile para referirse al acoso).
- Aislamiento: impedir que tenga vida social, obligarla a relacionarse sólo con el,
dificultar las relaciones con su red de amistades...
- Celos: acusarla de coquetear con otros, de estar interesada en otros, de ser
provocativa; desconfiar de su fidelidad y de sus muestras de afecto...
- Descalificación: criticar lo que hace o dice, hacer comentarios despectivos sobre
ella y sobre las mujeres en general, ridiculizarla, socavar su autoestima...
- Indiferencia afectiva: hacerle daño mostrándose insensible o desatento; ignorarla,
dejar de hablarle...
- Presióny negligencia sexual: imposición de relaciones sexuales no deseadas
mediante enfados o acusaciones, ignorar lo que ella desea, no responsabilizarse de
los riesgos, considerar que las medidas de protección son cosa de ella solamente...
Incluiria también la presión para tener relaciones sexuales.
- Manipulación emocional: chantaje afectivo para conseguir lo que quiere, hacerla
sentir mal si no hace lo que él quiere...
- Amenazas: amenaza de violencia fisica, de abandono, de dañarla a través de
objetos o personas queridas...
- Justificar la violencia psiquica del hombre hacia la mujer por imitación del
entorno familia, cultura, o cualquier tipo de justificación. Cualquier expresión que
contenga justificación de cualquier tipo de violencia psicológica (referida a los
apartados anteriores).
-

to be able to guarantee the credibility of the process. To test the dependability of the category system, we created a descriptive manual of the categories to perform the coding. Finally, confirmability was provided for the results through the inclusion of verbatim excerpts from the teenagers' discourses.

We produced a shorter version of a coding manual that was adapted from Delgado, Sánchez, and Santos (2012) and drew on the coding manual produced by experts in gender-based violence and presented in the AECID project report entitled Diagnóstico de la incidencia y formas de violencia doméstica por razones de género en mujeres aymaras urbanas de la región de Arica y Parinacota, Chile (2012), which helped in the coding of the information-that is, identifying the categories in the texts.

Image 3. Coding manual. Adapted from Delgado, Sánchez, and Santos (2013) and project report "Diagnóstico de la incidencia y formas de violencia doméstica por razones de género en mujeres aymaras urbanas de la región de Arica y Parinacota Chile (2012)

\section{PSYCHOLOGICAL VIOLENCE}

Control: knowing everything she does, with whom, controlling her way of dressing and grooming and thoughts... (being apprehensive/possessive) Harassment Watching and following her, waiting for her at the exit of the places she goes to without her wanting this, harassment over the phone... References to being apprehensive / ( a concept used in Chile to refer to harassment). Isolation: preventing the person from having a social life, forcing her to only interact with him, difficult relations with her network of friendships...

Jealousy: accusing her of flirting with others or being interested in others; of being provocative; doubting her loyalty and displays of affection...

Disparagement: criticizing what she does or says, making derogatory comments about her and women in general, deriding her, undermining her selfesteem...

Emotional indifference: hurting her through being insensitive or inattentive; ignoring her, not speaking to her...

Sexual negligence and pressure: imposition of undesired sexual relations through anger or accusations, ignoring what she wants, not being responsible for risks, considering that protection measures are only for the girl to consider... This would also include the pressure to have sex.

Emotional manipulation: emotional blackmail to get what he wants, making her feel bad if she does not do what he wants...

Threats: the threat of physical violence, of leaving her, of hurting her through objects or loved ones...

Justifying psychological violence by men towards women through imitating the family environment, culture, or any kind of justification. Any expression containing justification for any kind of psychological violence (referring to the previous sections).

\section{PHYSICAL VIOLENCE}

Physical manifestation of violence against women. Any physical act or reference to it, which may have as a result physical damage, blows, shoving... Justifying physical violence through imitating the family environment, culture, or any type of justification. Any expression containing justification for any kind of physical violence (referring to the previous section). 
$Y$ finalmente, en la tercera fase del análisis y en este artículo, se describen los resultados del análisis de contenido de las opiniones sobre las relaciones amorosas de los adolescentes entrevistados en los grupos de discusión (lo positivo y negativo de las mismas) y sobre conductas de violencia de género que existen en estas relaciones (psicológica y física).

\section{Resultados}

\subsection{Valoración de las relaciones iniciales de pareja}

La mayor parte de los discursos reflejan una valoración positiva general sobre las relaciones de pareja (19,60\% indexado en esta categoría sobre el total de las 7), destacando los beneficios de "salir con alguien". Sin embargo, también se señalan los aspectos negativos en términos de desventajas $(15,80 \%$ indexado en esta categoría sobre el total de las 7). En el análisis por género se pone de manifiesto que son los varones los que más desventajas encuentran en este tipo de relaciones, tal y como se constata en el siguiente gráfico.

Gráfico 3. Diferencias en los testimonios por categorías y género

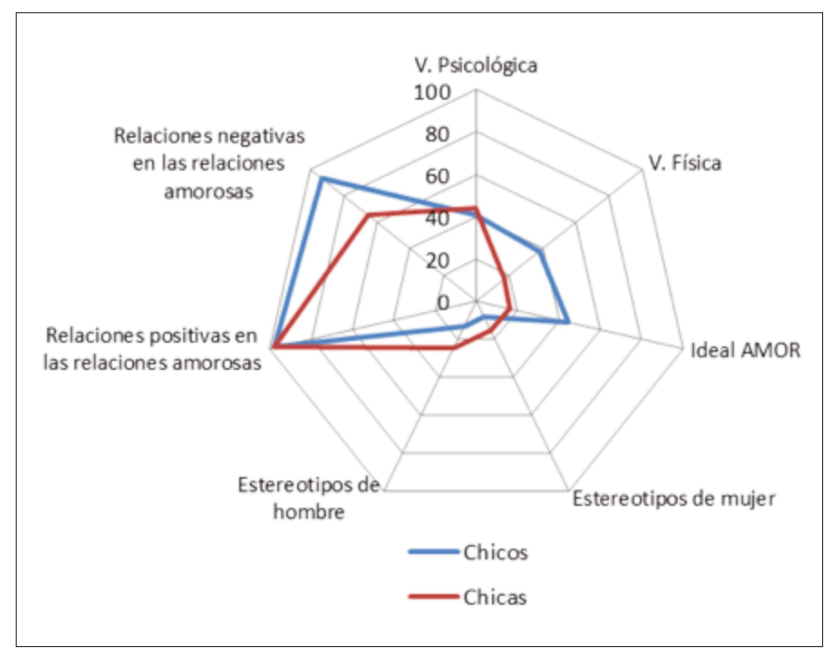

a. Adolescente/mujer: aspectos positivos de las relaciones de pareja

Para las chicas las relaciones amorosas tienen como aspectos positivos el que pueden aportarles protección, seguridad, apoyo por parte del chico, compañía, amor y cariño. Piensan que para que una relación funcione es necesario establecer un sentimiento de respeto mutuo y compartir tiempos.
Finally, in the third phase of the analysis-and in this article-we describe the results of the content analysis of the interviewed adolescents' (positive and negative) opinions on romantic relationships given during the discussion groups and on gender-based (psychological and physical) violence behaviors that exist in these relationships.

\section{Results}

\subsection{Assessment of initial couple relationships}

Most of the discourses reflect a general positive assessment of relationships $(19.60 \%$ indexed in this category out of the total of 7 categories) and highlight the benefits of "dating." However, negative aspects in terms of disadvantages (15.80\% indexed in this category out of the total of 7) were also pointed out. Analysis by gender highlights that males find more disadvantages in this type of relations, as the chart below shows.

Chart 3. Differences in accounta according to category and gender

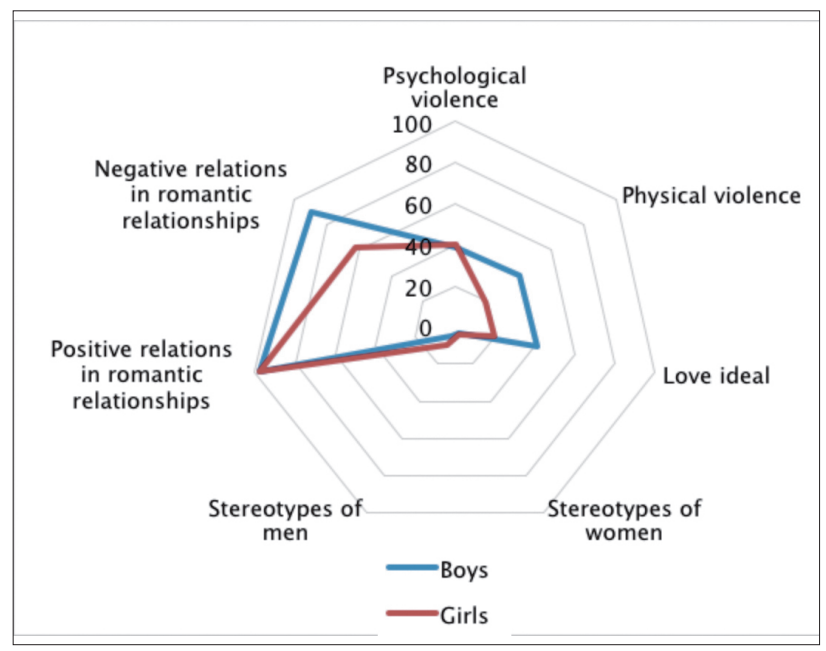

a. Adolescent/female: positive aspects of couple relationships

For girls, positive aspects of romantic relationships are that they can provide protection, security, support from the boy, companionship, love, and affection. They think that to make a relationship work it is necessary to establish a feeling of mutual respect and to spend time together.

[ 98 ] MARIA CRUZ SÁNCHEZ GÓMEZ, BEATRIZ PALACIOS VICARIO Y ANTONIO VÍCTOR MARTÍN GARCÍA 
b. Adolescente/mujer: aspectos negativos de las relaciones de pareja

En los aspectos negativos coinciden bastante con los chicos. Comparten la misma preocupación por la infidelidad, o la desconfianza, que bajo ningún concepto o explicación sería perdonable. Los celos y estar obligada a estar con el chico y alejarse de las amistades, el miedo a ser infelices, problemas de descuidar a la familia, problemas con los estudios son otras percepciones que comparten y, sobre todo, a las chicas les preocupa la posibilidad de quedarse embarazadas por la repercusión familiar, académica y social que tendría. La percepción de ellas sobre lo que les supone a los chicos la relación tiene que ver con la preocupación en empeorar el rendimiento académico y tener una pareja demasiado posesiva.

Imagen 4. Aspectos positivos y negativos de las relaciones para las chicas

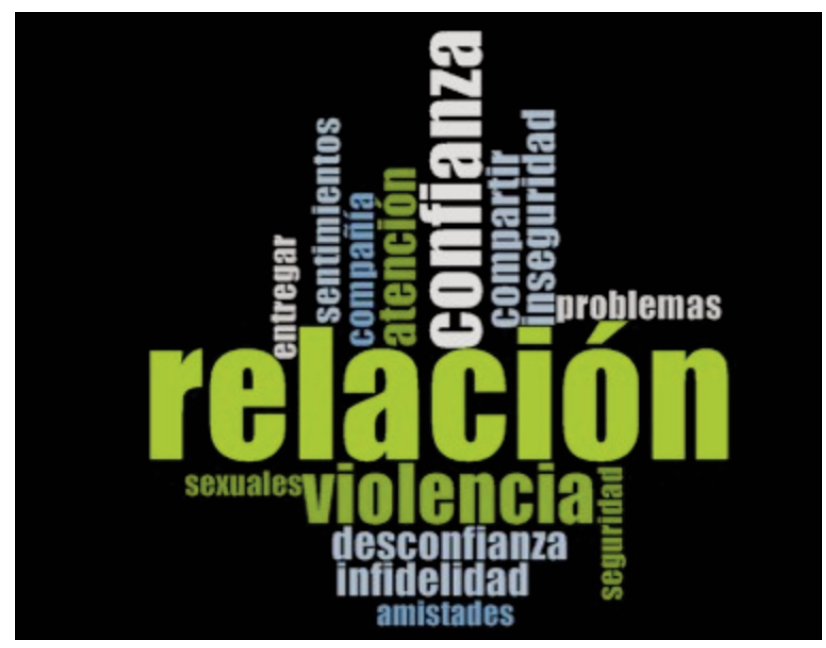

c. Adolescente/hombre: aspectos positivos de las relaciones de pareja

Para los chicos las relaciones amorosas son la forma de conocer a chicas e iniciarse en experiencias sexuales. Piensan que la relación les ayuda a ser más comprensivos y a madurar, puesto que en estos atributos ellas se consideran superiores. También creen que la finalidad de mantener una relación es básicamente llamar la atención de las chicas para tener relaciones sexuales. Tienen la percepción de que estas relaciones les aportan sobre todo afectividad, es decir, recibir cariño y sentirse querido, y además, aunque en menor me- b. Adolescent/female: negative aspects of couple relationships

To a large extent, girls coincide with boys on the negative aspects of relationships. They share the same distrust and concerns about infidelity, something that would not be forgivable under any circumstances or with any explanation. Jealousy and being forced to be with a boy and removed from friends, fear of being unhappy, problems with neglecting one's family, and school-related problems are other perceptions that they share and, above all, the girls worry about the possibility of becoming pregnant because of the family, academic, and social repercussions that it would have. The girls' perception about what a relationship means to boys relate to worries about worsening academic performance and having a partner who is too possessive.

Image 4. Positive and negative aspects of relationships for girls

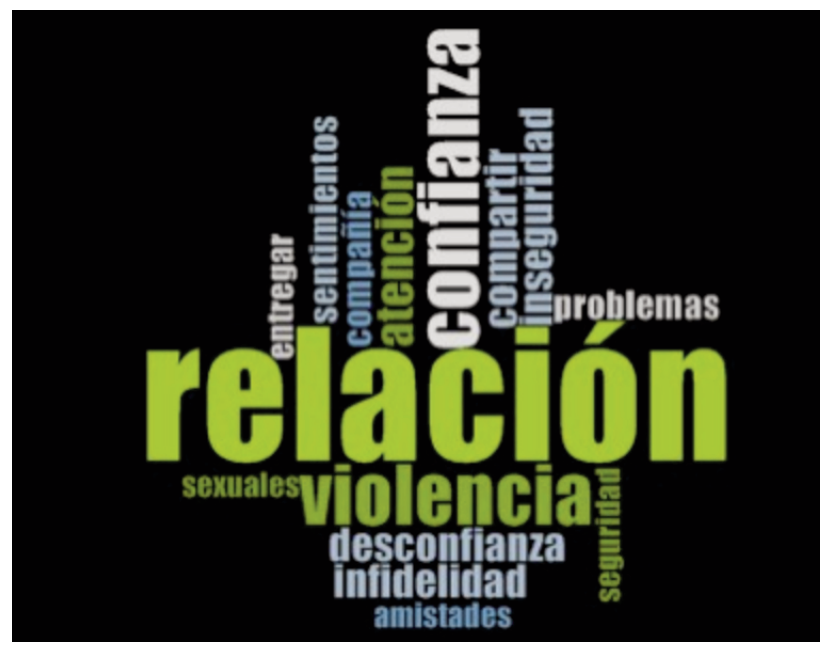

c. Adolescent/male: positive aspects of couple relationships

For boys, romantic relationships are a way to meet girls and gain sexual experiences. They think a relationship helps them to be more understanding and mature, since girls consider themselves superior with regard to these attributes. They also believe that the purpose of staying in a relationship is basically to get girls' attention in order to have sexual relations. They have the perception that these relationships bring them affection above all-that is, they receive and feel it, and in addition, though to a lesser extent, help, friendship, and confidence. Moreover, their per- 
dida, ayuda, amistad y confianza. En cambio, la percepción de ellos sobre lo que les supone a las chicas es similar a las características que ellas enfatizan: protección, el apoyo y la seguridad. Y ellos añaden la posibilidad de formar una familia, aumentar su libertad en relación al control parental y una mejora sustancial en el ahorro económico que supone para la chica tener pareja, ya que el chico parece verse obligado a hacerse cargo de invitar a la chica a determinadas actividades como ir al cine, tomarse un refresco o incluso sufragar las compras personales, y por supuesto agasajar con continuos regalos.

d. Adolescente/hombre: aspectos negativos de las relaciones de pareja

El abanico de características negativas de los chicos sobre sus relaciones amorosas es más amplio que en las chicas. Su discurso se divide en tres bloques, económico, emocional y las consecuencias de las relaciones amorosas. Como comentábamos anteriormente, lo económico es un factor muy importante a tener en cuenta para estos chicos a la hora de establecer una relación, ya que ven necesario hacerse cargo de la economía de la pareja. Este aspecto está relacionado directamente con los estereotipos masculinos, en la que el hombre es el proveedor económico de la familia, aunque en este caso es extensivo también a las relaciones amorosas. Lo emocional hace referencia, no al momento de tener una pareja sino al momento de volver a la "soltería", destacan problemas emocionales importantes como la depresión, situaciones de desequilibrio emocional como momentos de enojo/furia combinados con momentos de euforia. Las consecuencias hacen referencia al momento en el que mantienen la relación en el sentido de escaso rendimiento académico, embarazos no deseados y por lo tanto deben olvidarse de sus aspiraciones personales. También hay problemas de celos, tener una pareja demasiado posesiva; y al momento de dejar la relación, problemas de alcoholismo y violencia física hacia la chica si les deja. En cambio, según ellos, para la chica lo negativo de una relación serían los celos, el que el chico sea machista, la falta de comunicación y la infidelidad. ception of what relationships mean to girls is similar to the features that they emphasize: protection, support, and safety. And the boys add the possibility of starting a family, an increase in their freedom from parental control, and the superior money savings that a girl gets from having a partner, since the boy has to be responsible for treating the girl to activities such as going to the movies or for a drink, or even covering personal purchases-and of course continually lavishing gifts upon the girl.

d. Adolescent/male: negative aspects of couple relationships

The range of negative characteristics that boys attach to their relationships is wider than that of the girls. Their discourse can be divided into three blocks: economic, emotional, and the consequences of romantic relationships. As we previously mentioned, economic considerations are a very important factor to keep in mind for the boys when it comes to a relationship, because they think that it is necessary for them to take charge of the couple's finances. This aspect is directly linked with male stereotypes, according to which the man is the economic provider for the family, though in this case the stereotype is applicable to romantic relationships. The emotional elements here come not at the moment of having a partner, but at the moment of returning to "single life." They highlight significant emotional problems such as depression and situations of emotional imbalance, for example moments of anger or rage combined with moments of euphoria. "Consequences" refers to the time when a relationship is kept going during poor academic performance or unwanted pregnancies-factors that mean that they must abandon their personal aspirations. There are also problems of jealousy, having a partner who is too possessive, and, during the breakup of a relationship, alcoholism and physical violence towards the girl if she initiates the breakup. On the other hand, according to the boys, for the girl the negative aspects of a relationship are jealousy, a machista boyfriend who is sexist, a lack of communication, and infidelity. 
Imagen 5. Aspectos positivos y negativos de las relaciones para las chicas

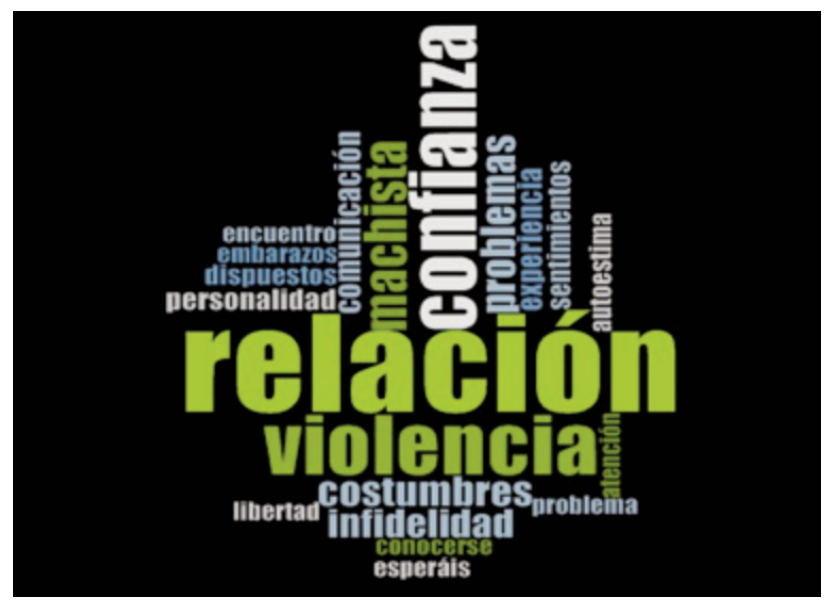

\subsection{Presencia y valoración de violencia de género}

Las dimensiones que hacen referencia a la violencia de género (psicológica y física) han aparecido con frecuencia en el discurso (14,72\%). Si tuviéramos en cuenta las categorías analizadas simultáneamente tendríamos que un $\mathbf{2 0 . 7 0} \%$ del discurso expresado está relacionado con variables vinculadas con la violencia de género que sufren las adolescentes en las relaciones de pareja.

\section{a) Violencia psicológica}

La subcategoría de violencia psicológica con mayor frecuencia en el discurso es la que hace referencia a los celos (30\%), seguida por los comentarios que atestiguan control, manipulación emocional, presión y negligencia sexual. Con menos presencia se perciben los que hacen referencia a amenazas, indiferencia afectiva y descalificación. En todas las subcategorías de violencia psicológica los chicos emiten más comentarios que las chicas, excepto en presión y negligencia sexual, en las que las chicas manifiestan más sus opiniones al respecto; es precisamente en las que se dan mayores diferencias entre hombres y mujeres, seguidas de control, celos e indiferencia afectiva en las que hay más observaciones en los chicos. También habría que destacar que no hay ningún comentario de las chicas que justifique la violencia psicológica y sí por parte de los chicos. Advertimos que las chicas mayores (las de $4^{\circ}$ secundaria) emiten más testimonios relativos a celos, control, manipulación emocional y sobre todo
Image 5. Positive and negative aspects of relationships for boys

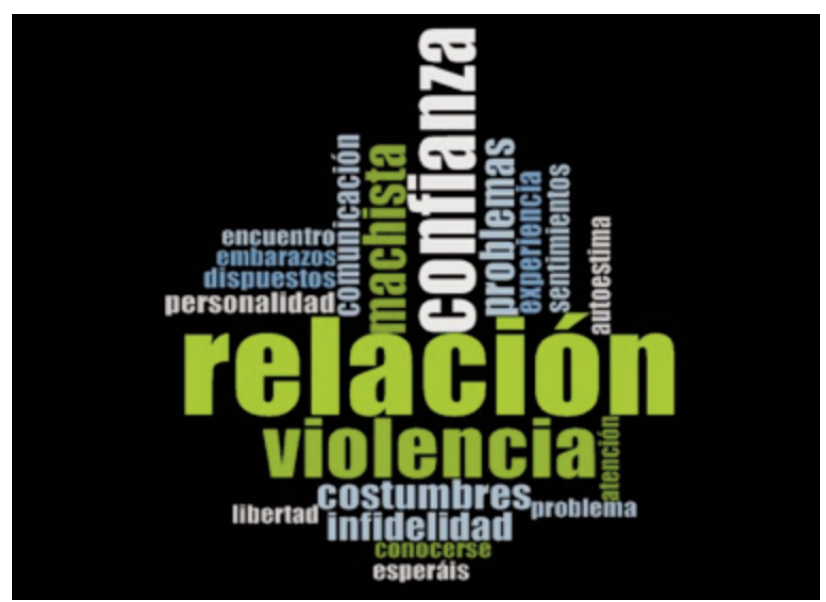

\subsection{Presence and assessment of gender-based violence}

The dimensions of gender-based violence (physical and psychological) appeared frequently in the discourses $(14.72 \%)$. If we keep in mind the simultaneously analyzed categories, $20.70 \%$ of the expressed discourse is relevant to variables that relate to gender-based violence suffered by adolescent girls in couple relationships.

\section{a) Psychological violence}

The subcategory of psychological violence that occurred most frequently in the discourses is references to jealousy (30\%), followed by comments that suggest control, emotional manipulation, and sexual negligence and pressure. Appearing less frequently, though still noted, were references to threats, emotional indifference, and disparagement. In all subcategories of psychological violence, the boys produced more comments than the girls, except with regard to sexual negligence and pressure, over which the girls expressed their views more frequently. This is precisely the area where the difference between the boys and girls was biggest, followed by control, jealousy, or emotional indifference, observed more in the boys. It should also be noted that no comment from the girls justified psychological violence, whereas there were comments from the boys that did. We should point out that older girls (those at the grade 11 level) have more personal accounts of jealousy, control, emotional manipulation, and, above 
de indiferencia afectiva. Las manifestaciones de chicos de $3^{\circ}$ y $4^{\circ}$ de secundaria son muy similares con relación a las distintas subcategorías de violencia psicológica. Sobre todo alegan control, celos y de manipulación emocional (más los chicos de $4^{\circ}$ ). En sus comentarios no hay datos de las subcategorías de acoso, aislamiento y amenaza.

Control: Indicador que muestra que el chico tiene siempre la razón, la autoridad, posesión de la chica, es el que manda en el hogar. Asocia el ser autoritario con un rasgo propio de ser machista. Las chicas comentan que los chicos suelen ser muy "aprensivos" en el sentido de controladores de lo que hacen ellas.

Celos. Reflejan situaciones de violencia en la pareja, así como falta de confianza y de respeto en la relación. En los discursos se aprecia que se dan más en los chicos que en las chicas, aunque también indican que una chica puede estar celosa pero, en este caso, sin violencia. Se observa una clara relación de los celos con la inseguridad y de estar muy enamorado con tener celos.

Descalificación. En este apartado se recogen referencias a críticas y comentarios despectivos sobre todo con relación a los aspectos físicos de las chicas. También hay observaciones despectivas de carácter psicológico como tontos, estúpidos, etc... Las chicas comentan que esto les duele y hablan sobre las muchas descalificaciones que sufren en este sentido. Los chicos son conscientes de las descalificaciones que hacen a las chicas. Ningún grupo de chicos hacen referencia a descalificaciones de las chicas hacia ellos.

Indiferencia afectiva. Solamente los chicos hacen algún comentario sobre este indicador en el sentido de jugar con los sentimientos de las chicas, a salir con ellas por su gusto, sin apoyarlas emocionalmente.

Presión y negligencia sexual: Las chicas comentan sobre todo que los chicos las presionan para tener "la prueba de amor" (sexo) y si ellas no quieren les hacen sentir que no corresponden a su amor. También las presionan o ellas sienten que si no tienen relaciones sexuales los chicos se irán con otra pareja. Los chicos no hablan casi nada de temas de esta cate- all, emotional indifference. The statements of boys at the levels of grade 10 and 11 are very similar with respect to the different subcategories of psychological violence. Above all, they cite control, jealousy, and emotional manipulation (mostly the grade 11 boys). There are no data in the subcategories of harassment, isolation, and threats.

Control: An indicator that shows that the boy is always right, has authority, has possession of the girl, and is in charge at home. Being authoritarian is linked with a particular trait of being macho. The girls say that boys tend to be very "apprehensive" in the sense of being controlling over what the girls do.

Jealousy: In this indicator the comments reflect situations of violence within the couple, as well as a lack of trust and respect in the relationship. We noticed that this indicator appeared more in the discourses of the boys than in those of the girls. That said, the discourses also suggest that the girls could be jealous, though in this case without violence. We observed a clear relationship between jealousy and insecurity, and between a belief of being intensely in love within the relationship and feelings of jealousy.

Disparagement. This section includes references to criticism and derogatory comments, above all in relation to girls' looks. There are also derogatory psychological comments such as "dumb," "stupid," and so forth. The girls made comments to the effect that these hurt them. The girls talk about being disparaged and the boys about disparaging girls. None of the groups of boys made a comment about being disparaged by a girl.

Emotional indifference. Only the boys made comments in this category, doing so in relation to playing with a girl's feelings, to going out with a girl for their own pleasure and without taking into account her feelings, and to not supporting her.

Sexual negligence and pressure: The girls spoke above all about boys pressuring them into the "proving their love" (through sex), saying that if they did not do so they were made to feel that they were not loved back. Boys also exerted the pressure-or the girls felt that they did-of leaving them for another partner if they did not have sexual relations. The

[ 102 ] MARIA CRUZ SÁNCHEZ GÓMEZ, BEATRIZ PALACIOS VICARIO Y ANTONIO VÍCTOR MARTÍN GARCÍA SIPS - PEDAGOGIA SOCIAL. REVISTA INTERUNIVERSITARIA [1139-1723 (2015) 26, 85-109] TERCERA ÉPOCA 
goría pero cuando lo hacen es para indicar que si dejan embarazadas a las chicas las abandonan.

Manipulación emocional. Las pocas referencias discursivas son de las chicas y tienen que ver con que hay que hacer lo que a los chicos les gusta, como estar siempre con ellos y no ser muy independientes, de lo contrario, las dejarán.

Justificación de la violencia psicológica por imitación entorno-familia-cultural u otros motivos. No hay ninguna justificación que exprese alguna relación de este tipo de violencia con temas culturales o familiares. Los varones relacionan estas conductas con discusiones, problemas, estrés de la relación (pololeo), despecho, celos, enojo, por romper la relación la chica e ira. Las mujeres no hacen comentarios al respecto. boys barely spoke about subjects within this category, but when they did it was to indicate that if they got a girl pregnant they would leave them.

Emotional manipulation. The few references to this were made by the girls, and they related to having to do what pleases boys, for example always being with them and not being very independent, on the grounds that otherwise boys would leave them.

Justification of psychological violence through environmental, family, or cultural imitation or other reasons. There was no justification that expressed a link between this type of violence and cultural or family factors. Boys related these behaviors with fights, problems, relationship (dating) stress, spite, jealousy, annoyance, ending a relationship with a girl, and anger. The girls did not make any comments on this subject.

Gráfico 4. General y por subcategorías de la violéncia psicológica y género

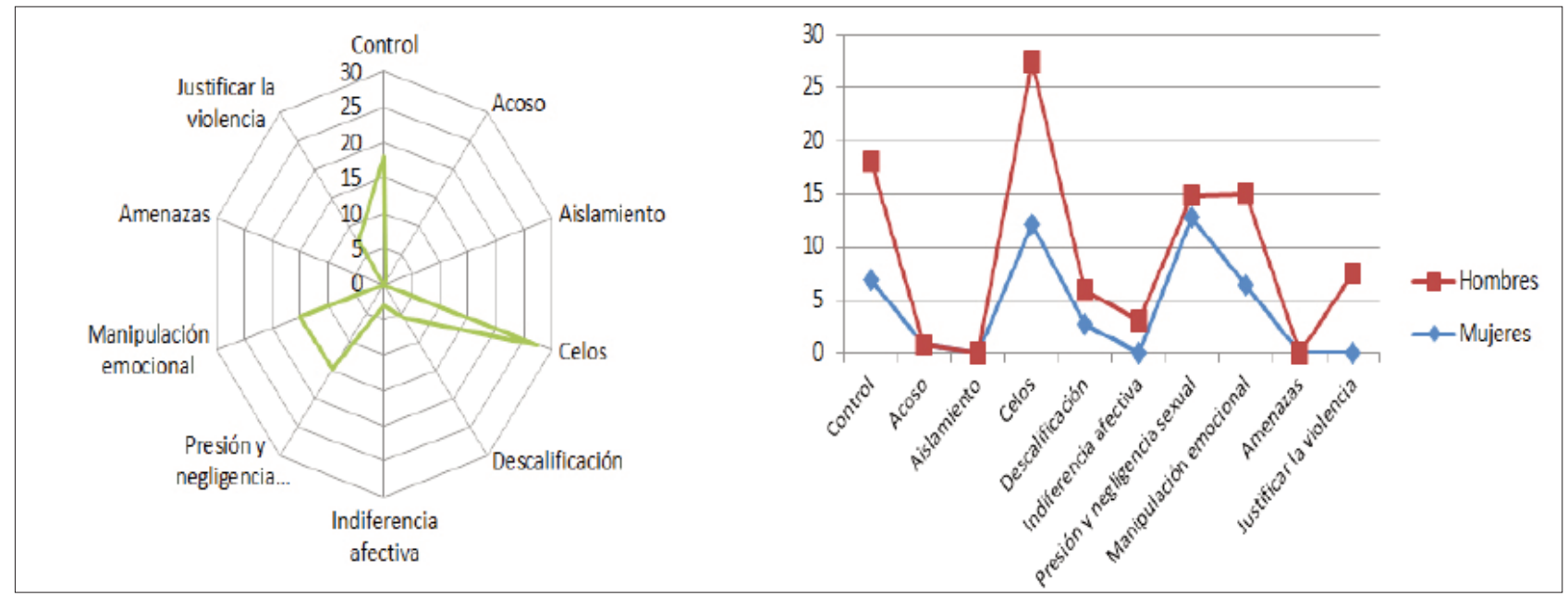

Chart 4. General and by subcategories for gender and psychological violence

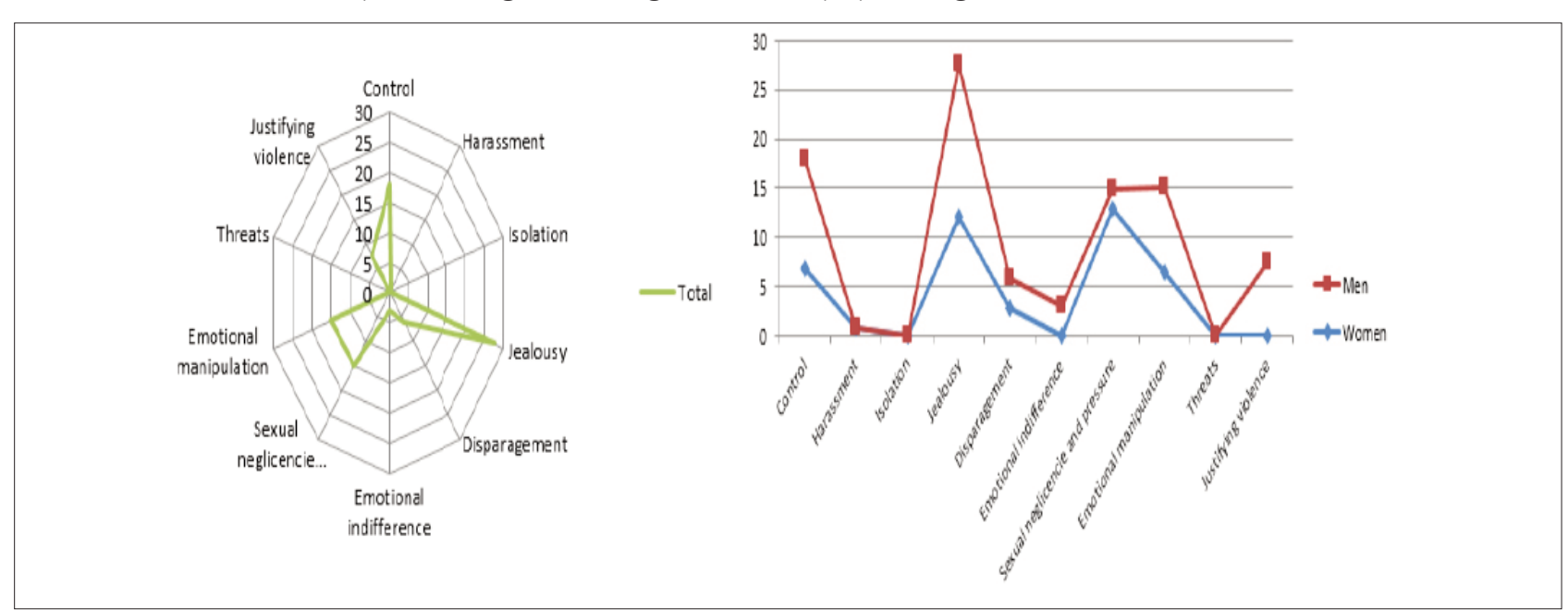

INDICADORES DE VIOLENCIA DE GÉNERO EN LAS RELACIONES AMOROSAS. ESTUDIO DE CASO EN ADOLESCENTES CHILENOS [ 103 ] 
b) Violencia física

Los que comentan este tema son los grupos de los adolescentes varones. Hablan de golpes o agresiones en las parejas de adolescentes, "pegar" porque las chicas no hacen lo que quieren los chicos o porque el joven no sabe resolver un problema mediante el diálogo. Otras razones son sentir celos o sentirse engañado. Ninguno comenta que haya agredido a su pareja pero afirman tener experiencias directas de haber visto maltrato físico en alguna relación amorosa de amigos o en miembros de la familia.

Justificación de la violencia física hacia la mujer por imitación del entorno, familia o cultura. En este caso no se justifica la violencia física hacia la mujer por motivos que tengan que ver con valores o creencias de tipo étnico o propio de la cultura a la que perte- b) Physical violence

The teenage boys were the group that made comments about this subject. They talked about hits and attacks within teenage couples, and "smacking" when girls do not do what the boys want, or when the boy does not know how to solve a problem by using words. Other reasons were feelings of jealousy or infidelity. None of them said that he had attacked his partner, but they claimed to have direct experiences of having seen physical abuse in a romantic relationship that involved friends or family members.

Justification of physical violence toward women through environmental, family, or cultural imitation. In this case, physical violence towards women was not justified through reasons related to values or beliefs tied to an ethnicity or those of individuals' origins,

Gráfico 5. General y por subcategorías de la violéncia física y género

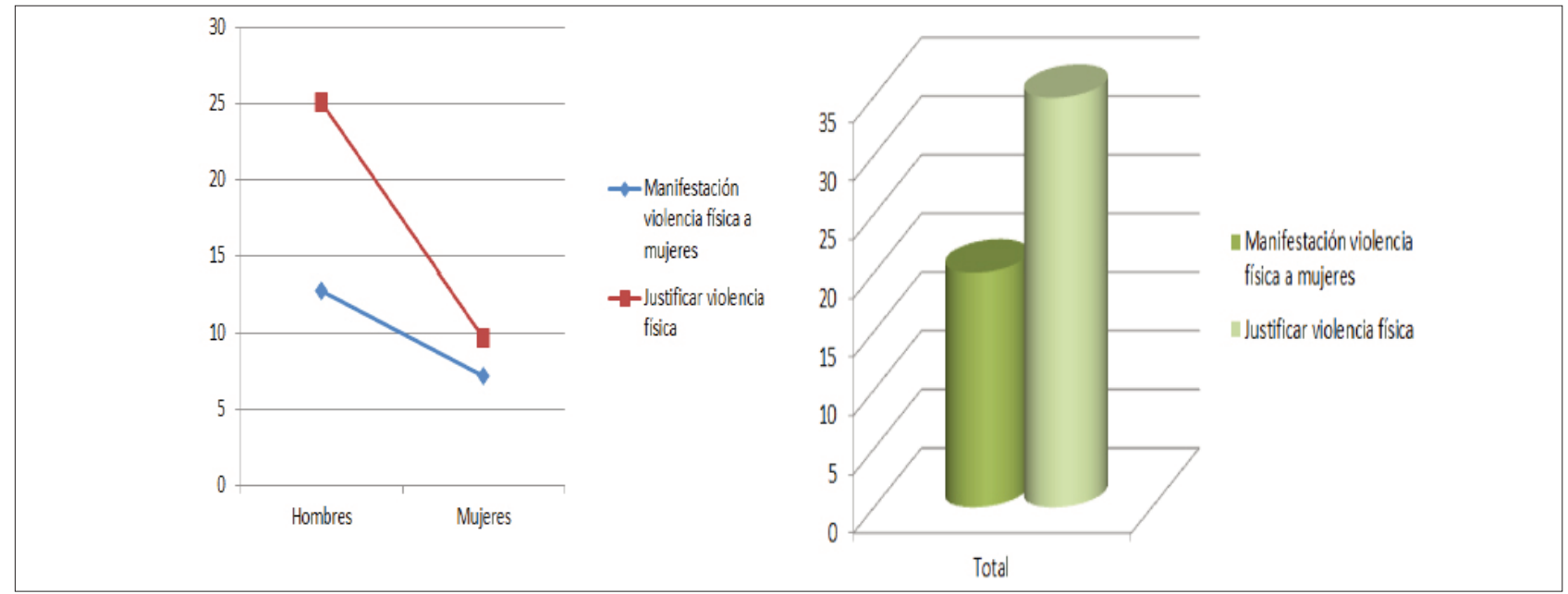

Chart 5. General and by subcategories for gender and physical violence

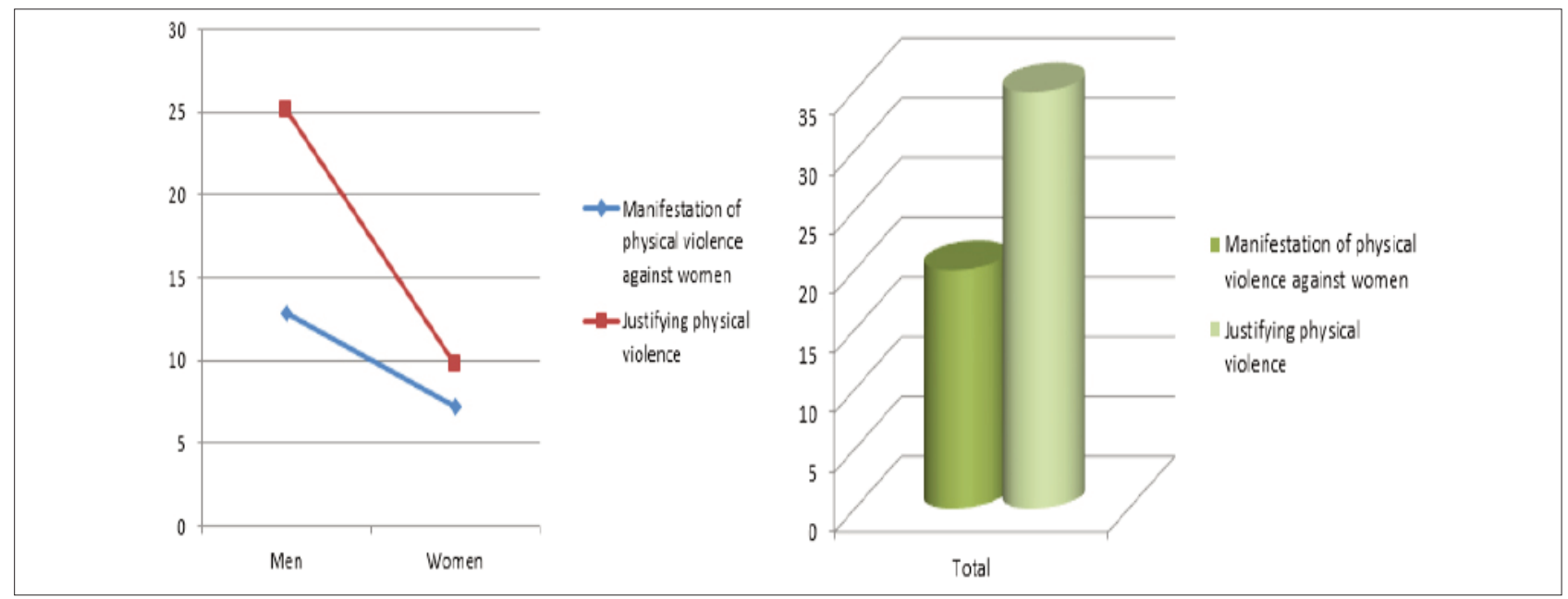

[ 104 ] MARIA CRUZ SÁNCHEZ GÓMEZ, BEATRIZ PALACIOS VICARIO Y ANTONIO VÍCTOR MARTÍN GARCÍA SIPS - PEDAGOGIA SOCIAL. REVISTA INTERUNIVERSITARIA [1139-1723 (2015) 26, 85-109] TERCERA ÉPOCA 
necen, pero sí porque hayan visto en casa que el padre maltrate a la madre.

\section{Discusión y Conclusiones}

A continuación y a modo de discusión se dará respuesta a las preguntas de investigación planteadas en el estudio. La primera cuestión es si se puede sustentar la violencia de género en una esquematización rígida roles de género, culturalmente asimilados. Los resultados de los análisis realizados esbozan una respuesta afirmativa; fuerza, poder y dominio aparecen como valores propios de la identidad masculina en las culturas latinas. Estos "valores" fundamentan estructuras de desigualdad, y un medio para alcanzarlos y defenderlos es la agresión. Como contrapartida, la identidad femenina ha sido elaborada con los atributos de debilidad, control y necesidad de protección. Estos valores son transmitidos como pautas de comportamiento deseable y se insertan en la propia identidad del sujeto que se convierte, pasando de un control externo de comportamientos, a un control interno que reproduce la ideología de los géneros (Unger y Crawford, 1996, Soriano, 2010). La característica esencial de este tipo de relación sería el desequilibrio de poder, a partir del cual la persona que ocupa la posición inferior adopta conductas positivas hacia la persona que la intimida y maltrata, como un medio de supervivencia psicológica (Delgado y Martín, 2004; Delgado et al, 2007). En el estudio se percibe también que las adolescentes tienen más interiorizados los patrones de género tradicionales que los chicos.

La segunda interrogación planteada es si pueden percibirse en las primeras relaciones amorosas de los adolescentes indicios de violencia de género. Gran número de estos rasgos están relacionados con las dimensiones de violencia de género y aparecen explícitamente señalados en los discursos recogidos en nuestra muestra de adolescentes, en los que se habla de temas como la violencia física, la violencia psicológica o del ideal de amor. Los resultados del estudio ponen de manifiesto que en estas primeras relaciones de pareja de los adolescentes hay un número importante de referencias a lo negativo y a comportamientos de violencia de género, sobre todo a la violencia psicológica. but it was justified on the grounds that they had seen their father abuse their mother at home.

\section{Discussion and Conclusions}

In the form of our discussion, we will now provide answers to the research questions posed by our study. The first question is whether gender-based violence is sustained within a rigid schematization of culturally assimilated gender roles. The results of the analysis conducted reveal an affirmative response; strength, power, and domination appear as values that characterize the masculine identity of Latino cultures. These "values" lay the foundations for structures of inequality, and a means to achieve and defend them is aggression. In contrast, the female identity is constructed through the attributes of weakness, control, and the need for protection. These values are transmitted as guidelines for desirable behavior and are incorporated into the subject's own identity, which becomes, progressing from an external control of behaviors, an internal form of control that reproduces gender ideology (Unger and Crawford, 1996; Soriano, 2010). The essential feature of this type of relationship seems to be an imbalance of power, from which the person who occupies the inferior position adopts, as a means of psychological survival (Delgado and Martín, 2004; Delgado et al, 2007), positive behaviors towards the person who intimidates and abuses. The study also revealed that adolescent girls internalize traditional gender models more than their male counterparts do.

The second question posed was whether signs of gender-based violence can be detected in adolescents' first romantic relations. Many of these traits are related to the dimensions of gender-based violence and are explicitly mentioned in the discourses collected in our sample of adolescents, in which they talk about of issues such as physical and psychological violence and love as an ideal. The results of the study have shown that in these first couple relationships involving teenagers there are a significant number of references to negative factors and to behaviors related to gender-based violence, especially in a psychological form.

The third question asks whether it is possible to produce educational initiatives that allow the prio- 
La tercera pregunta se refiere a si se pueden realizar propuestas educativas que permitan priorizar y diseñar programas de intervención para promover relaciones más igualitarias entre adolescentes y jóvenes, como medio de educar para la prevención de relaciones abusivas en las relaciones íntimas y desigualdades de género. Asumimos que el abordaje convencional de este complejo problema (medidas legislativas, policiales, penales, sociales, culturales, laborales) debe complementarse con otro enfoque, el educativo, en el que se propongan medidas de intervención y sobre todo medidas de prevención. El estudio de las percepciones del riesgo por parte de la población adolescente se ha mostrado como una clave importante para comprender las dinámicas de grupo y las relaciones interpersonales que contribuyen a la construcción de la identidad de los jóvenes. Consecuentemente, un esfuerzo institucional y una mejora en los programas de igualdad se presentan como un requisito inexcusable en la sociedad actual. El reciente estudio sobre la formación en género del estudiante universitario (Bas Peña; Pérez de Guzmán Puya y Vargas Vergara, 2014) pone de manifiesto que el alumnado desconoce el derecho a recibir este tipo de formación. Tampoco están informados sobre los Planes de lgualdad de sus universidades y, un alto porcentaje de estudiantes afirman que tanto ellos como un número elevado de docentes utilizan el lenguaje sexista en las aulas universitarias.

Todas estas evidencias formulan la discusión que se distribuye por todos y cada uno de los documentos analizados: la necesidad de seguir ampliando esfuerzos para encontrar nuevos métodos y estrategias de formación encaminadas a vislumbrar la situación de la mujer en el mundo para prevenir la ideología que sustenta las desigualdades. Algunos pasos se han dado, pero aún queda mucho camino por recorrer ya que todavía se evidencian actitudes que constatan valores sexistas, estereotipos de la mujer como objeto de deseo y sujeto de satisfacción masculina.

En resumen, la violencia de género sigue siendo uno de los problemas pendientes en las sociedades que pretenden avanzar hacia la igualdad de los sexos. Las inversiones en recursos sociales dirigidas a erradicar este problema no producen los efectos deseados y las cifras sobre violencia de género siguen siendo dramáticas tanto en Europa como en Lationamérica. Por este motivo es fundamental re- ritizing and design of intervention programs to promote more equal relations among adolescents and young people, as a way of preventing abusive intimate relationships and gender inequalities through education. We assume that the conventional approach to this complex problem (legislative, police, criminal, social, cultural, and labor measures) must be complemented with another approach-an educational one-in which intervention and above all preventive measures are proposed. The study of risk perceptions for the adolescent population has proven to be an important key for understanding group dynamics and interpersonal relationships that contribute to the construction of the identity of young people. As a result, an institutional effort and an improvement in equality programs appear to be an inevitable requirement in today's society. The recent study on gender training for university-level students (Bas Peña; Pérez de Guzmán Puya and Vargas Vergara, 2014) reveals that students are unaware of the right to receive this type of training. Nor are they informed of their universities' equality plans, and a high percentage of students say that both their peers and a large number of teachers use sexist language in the university classroom.

All these pieces of evidence shape the discussion that is found across each and every one of the analyzed documents: the need to continue to expand efforts to find new educational strategies and methods that aim to shed light on the situation of women in the world in order to prevent the ideology that sustains inequalities. Some steps have already been taken, but there is still long way to go. There are demonstrably still attitudes that confirm sexist values and sexist stereotypes of women as objects of desire and the subject of male satisfaction.

In short, gender-based violence continues to be one of the outstanding problems in societies that are attempting to move toward equality between the sexes. Investments in social resources aimed at eradicating this problem have not produced the desired effects, and the figures on violence against women continue to be shocking, both in Europe and in Latin America. For this reason, it is essential to strengthen and expand pre-

[ 106 ] MARIA CRUZ SÁNCHEZ GÓMEZ, BEATRIZ PALACIOS VICARIO Y ANTONIO VÍCTOR MARTÍN GARCÍA SIPS - PEDAGOGIA SOCIAL. REVISTA INTERUNIVERSITARIA [1139-1723 (2015) 26, 85-109] TERCERA ÉPOCA 
forzar y ampliar los programas preventivos dirigidos a los grupos de menor edad. El Ministerio de Educación Chileno no dispone de programas educativos en temas de igualdad de género y violencia hacia la mujer, pero sí existen acciones de interés como por ejemplo el "Programa Alerta Temprana" y "Pololeo sin Violencia" diseñados e implementados por el Servicio Nacional de la Mujer. Estos programas pretenden en el ámbito local, prevenir la violencia intrafamiliar, mediante la implementación de un modelo de intervención integral enfatizando la prevención comunitaria y especialmente el trabajo en la primera infancia, y con adolescentes en la construcción de relaciones amorosas no agresivas. ventive programs aimed at younger age groups. Chile's Ministry of Education does not have educational programs on issues of gender equality and violence against women, but there are relevant initiatives, such as the "early alert program" and "dating without violence," both of which were designed and implemented by the National Women's Service. These programs are aimed at the local level, and they prevent domestic violence through the implementation of a model of integrated intervention that emphasizes communitybased prevention and in particular focusing on early childhood and working with teens on the construction of nonaggressive relationships.

\section{Rerencias Bibliográficas/ Bibliographic References}

Bas, E; Pérez de Guzmán, V; Vargas, M (2014). Educación y Género: la formación de los educadores y educadoras sociales. Pedagogía Social. Revista Interuniversitaria, 23, 95-120. doi: 10.7179/PSRI_2014.23.05

Bosch, E., \& Ferrer, V. (2002). La voz de las invisibles. Las víctimas de un mal amor que mata. Madrid: Cátedra.

Bosch, E., Ferrer, V., \& Alzamora, A. (2006). El laberinto patriarcal. Reflexiones teórico-prácticas sobre la violencia de género. Barcelona: Anthropos.

Cantera, l.; Estébanez, I., \& Vázquez, N. (2009) Violencia de género jóvenes: la violencia psicológica en las relaciones de noviazgo. Módulo psicosocial de Deusto. San Ignacio. Bilbao

Delgado, C., \& Mergenthaler, E. (2011). Evaluación psicométrica de la percepción de la violencia de género en la adolescencia. International Journal of Developmental and Educational Psycholoy. INFAD. Revista de Psicología no 1.vol.2, 197-206

Delgado, C., y Martín, M. F. (2004). Falsas creencias sobre la violencia de género. Grupo de investigación: Psicología y Género y ADAVAS-Salamanca. Manuscrito no publicado. Salamanca: Universidad Pontificia Salamanca.

Delgado, C., Martín, M. F., Iraegui, A., Marquina, L., Palacios, B., Plaza, ... Sánchez, Ma C. (2007). Perfil del maltratador y la victima de la violencia de género. In Guillén, C. \& Guil, R. (Eds.), Psicología Social: Un encuentro de perspectivas (972-980). Cádiz: Asociación de Profesionales de Psicología Social.

Díaz-Aguado. (2000). Superación del sexismo y rechazo a la violencia entre las/os adolescentes. In I. Mujer (Ed.), Las mujeres en el año 2000. Hechos y aspiraciones (55-68). Madrid: Instituto de la Mujer.

Díaz-Aguado. (2003). Adolescencia, sexismo y violencia de género. Papeles del Psicólogo, 84, 35-44.

Díaz-Aguado. (2006). Sexismo, violencia de género y acoso escolar. Propuestas para una prevención integral de la violencia. Revista de Estudios de Juventud, 73(junio), 38-57.

European Union Agency for Fundamental Rights (2014). European Violence against women: an EU-wide survey. Recuperado de

http://fra.europa.eu/sites/default/files/fra-2014-vaw-survey-main-results_en.pdf

Guba, E., \& Lincoln, Y. (1989). Fourth generation evaluation. Newbury Park: Sage.

Heyzer, N. (2000). Trabajando por un mundo libre de vilencia contra la mujer. In Carpeta de Documentos del Foro Mundial de Mujeres contra la Violencia (13-24). Valencia: Centro Reina Sofía para el Estudio de la Violencia.

INE (2002). Instituto Nacional de Estadística chileno. Retrieved from http://www.ine.cl/canales/chile_estadistico/estadisticas_sociales_culturales/etnias/pdf/info_etniascenso2002.pdf 
Informe sobre Diagnóstico de la incidencia y formas de violencia doméstica por razones de género en mujeres aymaras urbanas de la región de Arica y Parinacota. Chile. Código del Proyecto/Acción: A/O33951/10 (2012). Memoria presentada en la Agencia de Cooperación Española Internacional para el Desarrollo (AECID)

Ley Orgánica de Medidas de Protección Integral contra la Violencia de Género, 1/2004 de 28 de diciembre. Lincoln, Y.S., \& Guba, E.G. (1985). Naturalistic inquiry. Beverly Hills: Sage.

Ministerio de Sanidad, Servicios Sociales e Igualdad (2015). Datos estadísticos de violencia de género. Retrieved from http://www.msssi.gob.es/ssi/violenciaGenero/datosEstadisticos/home.htm

Moreno, M; Sastre, G., \& Hernández, J. (2003). Sumisión aprendida: un estudio sobre la violencia de género. Anuario de psicología, vol. 34, $\mathrm{n}^{\circ} 2,235-251$

Organización de Naciones Unidas (ONU) (1994). Declaración sobre la eliminación de la violencia de género (Res $A / R / 48 / 104)$. New York: Naciones Unidas.

Organización de Naciones Unidas ONU (2013). Centro de Noticias ONU http://www.un.org/spanish/ News/story.asp?NewsID=26760

Observatorio de Equidad de Género en Salud (OEGS) (2013). Informe Monográfico 2007-2012. Violencia de Género en Chile. Retrieved from http://www.paho.org/chi/index.php?option=com_docman\&task= doc_view\&gid=123\&Itemid

Observatorio contra la violencia doméstica y de género (2014). La violencia sobre la mujer en la estadística judicial: Datos anuales de 2013. Retrieved from http://www.poderjudicial.es/cgpj/es/Temas/Violencia_domestica_y_de_genero/Actividad_del_Observatorio/Datos_estadisticos/La_violencia_sobre_la_mujer_en_la_estadistica_judicial_Datos_anuales_de_2013

Palacios, B.; Sánchez, Ma C. \& Gutiérrez, A. (2013) Evaluar la calidad en la investigación cualitativa. Guías o checklists. Actas del Congreso Nacional de Metodología de la Investigación en Comunicación. Segovia: 2 y 3 de mayo

Sánchez, Ma C.; Delgado, Ma C. \& Santos, Ma C. (2012) Manual de procedimiento en la investigación cualitativa. Valladolid: Editorial Edintras

Santos, Ma C. (2009). Subtexto de género en los mensajes entre jóvenes. Aplicaciones para una educación en igualdad. (Tesis doctoral). Universidad Pontificia de Salamanca.

Servicio Nacional de la Mujer de Chile (SERNAN) (2009). Análisis de la Violencia en las Relaciones de Pareja entre Jóvenes. Disponible en las bases de datos de www.sernam.cl

Servicio Nacional de la Mujer de Chile (SERNAN) (2011). Violencia intrafamiliar en cifras. Encuesta de prevalencia de la violencia intrafamiliar. Disponible en las bases de datos de www.sernam.cl

Servicio Nacional de la Mujer de Chile (SERNAN) (2015). Tasas de feminicidios. Retrieved from http://portal.sernam.cl/img/upoloads/Femicidios_2014.pdf

Soriano, A. (2011). La violencia en las relaciones de pareja en estudiantes universitarios. Propuestas educativas. Pedagogía Social. Revista Interuniversitaria, 18. 87-97

Strauss, A., \& Corbin J. (1994). Grounded Theory Methodology. An Overview. In Denzin, N. K. y Lincoln, Y. S. (eds.). Handbook of Qualitative Research (273-285). Thousand Oaks: Sage,

Unger, R. k., \& Crawford, M (1996) Women and gender: A femenist psychology. Nueva York: McGraw- Hill.

\section{Notas}

1 Proyecto subvencionado por la Agencia de Cooperación Internacional para el Desarrollo con el título "Diagnóstico de la incidencia y formas de violencia doméstica por razones de género en mujeres Aymaras urbanas de la región de Arica y Parinacota. chile ( Ref. A/O33951/10) desarrollado a lo largo de año 2011.

\section{Notes}

1 Project conducted over the course of 2011, entitled "Diagnóstico de la incidencia y formas de violencia doméstica por razones de género en mujeres Aymaras urbanas de la región de Arica y Parinacota, Chile" ("Diagnosis of the incidence and

[ 108 ] MARIA CRUZ SÁNCHEZ GÓMEZ, BEATRIZ PALACIOS VICARIO Y ANTONIO VÍCTOR MARTÍN GARCÍA SIPS - PEDAGOGIA SOCIAL. REVISTA INTERUNIVERSITARIA [1139-1723 (2015) 26, 85-109] TERCERA ÉPOCA 
forms of gender-motivated domestic violence encountered by urban Aymara women in the Arica and Parinacota region, Chile"; Ref. A/O33951/10) and funded by the Spanish Agency for International Development Cooperation (Agencia de Cooperación Internacional para el Desarrollo).

\section{CÓMO CITAR ESTE ARTÍCULO / HOW TO CITE THE ARTICLE}

Sánchez Gómez, M. C., Palacios Vicario, B., \& Martín García, A. (2015). Indicadores de violencia de género en las relaciones amorosas. Estudio de caso en adolescentes chilenos. Pedagogía Social. Revista Interuniversitaria, 26 85-109. DOI:10.7179/PSRI_2015.26.04

Fecha de recepción del artículo / received date: 15.V.2014

Fecha de revisión del artículo / reviewed date: 18.V.2014

Fecha de aceptación final / accepted date: 05.11 .2015

\section{DIRECCIÓN DE LAS AUTORAS/ AUTHORS' ADDRESS}

Maria Cruz Sánchez Gómez. Antonio Víctor Martín García . Universidad de Salamanca, Dirección de correo/e-mail: mcsago@usal.es, avmg@usal.es. Beatriz Palacios Vicario Universidad Pontificia de Salamanca. Dirección de correo/e-mail: bpalaciosvi@upsa.

\section{PERFIL ACADÉMICO / ACADEMIC PROFILE}

Maria Cruz Sánchez Gómez. Doctora y Licenciada en Ciencias de la Educación en la Universidad de Salamanca y Máster en Logopedia en la Universidad Pontificia de Salamanca. Profesora Titular del Departamento de Didáctica, Organización y Métodos de Investigación de la Universidad de Salamanca con perfil en métodos de investigación y diagnóstico en educación. Sus áreas de trabajo están relacionadas con las Nuevas Tecnologías (investigadora de grupo de Excelencia), colectivos con riesgo de exclusión social y evaluación educativa (con miembros de MIDE ). En 2008 recibió primer el Primer Premio Nacional de Investigación de la Obra Social Caja Madrid y el Premio Perfecta Corsellas de Investigación Educativa en 2014. Directora del Servicio de Formación Continua de la Universidad de Salamanca (2007/2010).

Beatriz Palacios Vicario. Dra.en Psicología y licenciada en Psicopedagogía por la Universidad Pontificia de Salamanca (UPSA). Imparte docencia en la Facultad de Psicología, Magisterio y en Ciencias de la Actividad Física y del Deporte de la UPSA, concretamente, en las asignaturas de Investigación cualitativa y Metodología de la Investigación en Educación e Innovación. También imparte docencia en varios Másteres de la UPSA y de la Universidad de Salamanca (UPSA). En el ámbito de la investigación, sus trabajos se centran en tres líneas de investigación acerca de Educación y Género; Educación y Nuevas Tecnologías; y Metodología de la Investigación en las CC del Comportamiento y Sociales. Cuenta con numerosas publicaciones, participación en congresos nacionales e internacionales, así como la dirección de tesis doctorales. Es miembro del grupo de investigación del Centro de Tecnología Avanzadas de la Fundación Germán Sánchez Ruiperez, y del grupo de Investigación PSIGEMI de la UPSA

Antonio Víctor Martín García. Profesor Titular de Pedagogía Social de la Universidad de Salamanca. Director del Máster Oficial “Estudios Avanzados de Educación en la Sociedad Global”. Ha participado en varios proyectos internacionales de cooperación e investigación en educación social. Sus líneas de especialización docente y de investigación actuales tienen que ver conla Educaciónde Personas Adultas, Gerontología Educativa y las TICs aplicadas a la educación. Miembro del Grupo de Investigación Reconocido (GIR) “Procesos, Espacios y Prácticas Educativas" y del "Grupo 90 en Educación de Adultos”. Es autor y/o coautor de varios libros y artículos, todos ellos enfocados desde la perspectiva de la educación y la pedagogía social. 
